\title{
REFORMING INTERNATIONAL HUMAN RIGHTS Litigation Against CORPORATE DEFENDANTS AFTER JESNER V. ARAB BANK
}

\section{Gerlinde Berger-Walliser*}

INTRODUCTION

I. JESNER, CORPORATE SOCIAL RESPONSIBILITY AND HUMAN RIGHTS

A. The Current State of the Business and Human Rights

Relationship.

1. Emergence and Development of the Business and Human Rights Debate.

2. Corporate Embrace of Business and Human Rights. 767

3. Business and Human Rights Regulation.....................769

B. Human Rights and ATS Litigation in the United States 773

C. The Jesner Decision

II. THE ATS AND JURISDICTION OVER FOREIGN DEFENDANTS IN U.S.

COURTS 780

A. The ATS as Jurisdictional Statute 781

B. Personal Jurisdiction over Foreign Corporate Defendants in International Human Rights Cases. 786

1. "At Home" General Jurisdiction. 787

2. Agency Relationship Based Specific Jurisdiction ....789

III. FOREIGN CORPORATE DEFENDANTS IN INTERNATIONAL HUMAN

RIGHTS LITIGATION IN THE EUROPEAN UNION ......................792

A. The European Jurisdictional Regime.................................793

B. Brussels Regulation and Human Rights ............................796

1. General Jurisdiction ..................................................796

\footnotetext{
* Assistant Professor of Business Law, University of Connecticut School of Business. Professor Berger-Walliser writes on international and comparative business law, sustainable governance, proactive law and legal design. She holds the First and Second German State Examination in Law, a Ph.D. in Law from the University of Bielefeld (Germany) and a Licentiate in International Law involving the United States from UC Davis School of Law. She was admitted to the German bar and held academic positions in Germany and France. 2100 Hillside Road Unit 1041, Storrs, Connecticut 06269, gerlinde.berger-walliser@uconn .edu. An earlier version of this article was presented at the University of Pennsylvania Journal of Business Law and University of Maryland's Center for the Study of Business Ethics, Regulation \& Crime 2019 Symposium on Harmonization of Business Law. The author is grateful to Taylor C. E. Eagan, and Jordan Greenlee for their editorial and research assistance. Financial support from the University of Connecticut School of Business' Fund is gratefully acknowledged.
} 
2. Derivative Special Jurisdiction based on a Subsidiary's

Domicile. 799

3. Special Tort Jurisdiction ............................................... 801

4. Special Jurisdiction for Connected Claims ................ 804

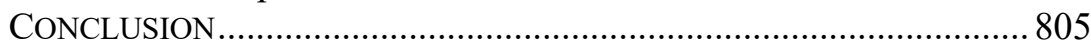

\section{INTRODUCTION}

In April 2018, the United States Supreme Court, in Jesner v. Arab Bank, $P L C$, denied terror victims in Israel access to U.S. courts, holding in a 5-to4 vote, that foreign corporations may not be sued under the Alien Tort Statute (ATS). ${ }^{1}$ The petitioners alleged that Arab Bank, a Jordanian financial institution, had facilitated acts of terrorism by maintaining bank accounts for known jihadists, and that it had used its New York branch to clear transactions and launder money for a US-based charity said to be affiliated with Hamas. Faced with the question whether liability under the ATS extends to foreign corporations, the Court found that there was no international custom to hold corporations liable for human rights abuses. The majority argued that the ATS was of jurisdictional nature and courts regularly could not use it to create new private rights of action. ${ }^{2}$ This task should be left to the legislator, especially on issues, which, like the present case, involved foreign policy concerns. ${ }^{3}$ Based on its restrictive interpretation of the ATS, the Court concluded that U.S. courts did not have jurisdiction over foreign-based Arab Bank.

The decision is said to deal the deathblow to United States human rights litigation. ${ }^{4}$ For almost 40 years, plaintiffs from around the world have used the ATS to bring human rights claims between foreign plaintiffs and

1. Jesner v. Arab Bank, PLC, 138 S. Ct. 1386 (2018); see 28 U.S.C. $§ 1350$ (2012) (indicating that the ATS provides that " $[\mathrm{t}]$ he district courts shall have original jurisdiction of any civil action by an alien for a tort only, committed in violation of the law of nations or a treaty of the United States").

2. See Jesner, 138 S. Ct. at 1389 (citing Sosa v. Alvarez-Machain, 542 U.S. 692, 71314 (2004)) (explaining that in Sosa, the Court held that ATS litigation implicates serious separation-of-powers and foreign-relations concerns).

3. See id. at 1399 (pointing to "significant diplomatic tensions" the litigation has caused "with Jordan for more than a decade").

4. Bastian Brunk, The Supreme Court Deals the Death Blow to US Human Rights Litigation, CONFLICT OF LAWS.NET (last visited Sept. 25, 2018), http://conflictoflaws.net/2018 /the-supreme-court-deals-the-death-blow-to-us-human-rights-litigation/ [https://perma.cc/U2 6T-E3FM] (concluding that the Supreme Court "has rendered human rights litigation against foreign corporations before US courts impossible," but that the ATS remains "applicable if the defending corporation has its seat in the territory of the [United States]"). 
defendants before U.S. federal courts. ${ }^{5}$ For decades, the United States legal system, with features such as class action lawsuits, discovery, jury trials, contingency fees, and potentially high damage awards was not only more attractive to plaintiffs than many other - though arguably closer connectedforeign forums, ${ }^{6}$ U.S. courts were sometimes the only available forum for victims or their heirs to pursue their rights. ${ }^{7}$ Nevertheless, even human rights promoting businesses and foreign governments have frequently criticized the far-reach and scope of U.S. courts' human rights litigation under the ATS. ${ }^{8}$ They feel that the long arm of U.S. jurisdiction encroaches on their sovereign rights. ${ }^{9}$ Jesner, at the detriment of international human rights victims, could end the U.S. federal courts' controversial role as the world's "human rights

5. Starting with Filartiga v. Pena-Irala, 630 F.2d 876, 878 (2d Cir. 1980), few cases have been successful to date; however, researchers have found positive spillover effects of even unsuccessful litigation or settlements on the advancement of human rights protection in the corporate setting. See generally Judith Schrempf-Stirling \& Florian Wettstein, Beyond Guilty Verdicts: Human Rights Litigation and its Impact on Corporations' Human Rights Policies, 145 J. Bus. Eтнісs 545 (2017) (reviewing the potential of non-judicial side effects of human rights litigation).

6. See Seth Davis \& Christopher A. Whytock, State Remedies for Human Rights, 98 B.U. L. Rev. 397, 418-19 n.125 (2018) (noting that there is empirical evidence that the U.S. legal environment may be less favorable to plaintiffs "as it supposedly once was, and that other countries will increasingly draw litigants to their courts through a combination of ex ante forum selection agreements and ex post forum shopping") (citing Marcus S. Quintanilla \& Christopher A. Whytock, The New Multipolarity in Transnational Litigation: Foreign Courts, Foreign Judgments, and Foreign Law, 18 Sw. J. InT'L L. 31, 33 (2011)).

7. On the difficulty for plaintiffs to find relief in the host state, see GWYNNE SKINNER, Robert McCorquodale \& Olivier De Schutter, The Third Pillar: Access to Judicial REMEDiES For Human Rights Violations by TRANSNATional Business 24 (2013) (listing lack of a functioning judicial system, danger of persecution of victims, legal tradition and culture, and legal costs as the main reasons for why host state litigation is often challenging); see also infra Part III (showing recent trends in Europe to give human rights victims effective access to MNCs' home-state courts).

8. See Jesner, $138 \mathrm{~S}$. Ct. at 1398 (noting objections to ATS litigation expressed by multiple foreign governments during the Kiobel litigation); see also Daimler A.G. v. Bauman, 571 U.S. 117, 141-42 (2014) (internal citation omitted) (holding that the Court was informed by the Solicitor General 'that 'foreign governments' objections to some domestic courts' expansive views of general jurisdiction have in the past impeded negotiations of international agreements on the reciprocal recognition and enforcement of judgments"'); see Caroline Kaeb \& David Scheffer, The Paradox of Kiobel in Europe, 107 AM. J. InT'L L. 852, 857 (2013) (noting with regard to the Kiobel decision that "[d]espite opposition by the British and Dutch governments to the extraterritorial reach of the ATS, the European view on the issue is far from settled and shows a trend towards extraterritoriality - however tame it may appearspearheaded by the European Commission").

9. See Doe v. Exxon Mobil Corp., 654 F.3d 11, $77-78$ (D.C. Cir. 2011) (listing objections to extraterritorial application of the ATS by national governments), cited by Kiobel v. Royal Dutch Petroleum Co., 569 U.S. 108 (2013). 
watchdog."10

The decision comes on the heels of Kiobel v. Royal Dutch Petroleum Co. ${ }^{11}$ In this equally controversial 2013 opinion, the Supreme Court held that courts may recognize a cause of action under the ATS for violations of human rights in the territory of a foreign state only "where the claims touch and concern the territory of the United States ... with sufficient force."12 Because Kiobel was a dispute between Nigerian nationals against foreign corporations for human rights violations committed in Nigeria, the Supreme Court denied a cause of action. This left open the question addressed in Jesner: where a sufficient connection to the U.S. territory is given, does liability under the ATS extend to corporate defendants? Because the Court granted certiorari to address this question shortly after it had decided Kiobel, the negative outcome in Jesner came as a surprise to many. ${ }^{13}$

However, this article argues that the decision is far from serendipitous. It seems consistent with not only Kiobel, but the Supreme Court's reasoning in other recent decisions. For example, in Goodyear Dunlop Tires $S A v$. Brown, ${ }^{14}$ Daimler A.G. v. Bauman, ${ }^{15}$ and Bristol-Myers Squibb Co. v. Superior Court, ${ }^{16}$ the Court has limited personal jurisdiction over foreign corporations based on similar foreign policy concerns as those expressed in Kiobel and Jesner. In Daimler, the only ATS case in the triad, the Court denied personal jurisdiction over foreign headquartered defendant Daimler

10. Marc-Philippe Weller, Luca Kaller \& Alix Schulz, Haftung deutscher Unternehmen für Menschenrechtsverletzungen im Ausland, 216 ARCHIV FÜR CIVILISTISCHE PRAXIS 387, 391-92 (2016) (Ger.) (citing Coester-Waltjen, FESTSCHRIFT FÜR RolF SCHÜTZE 27, 28 (2014)) (stating that recent developments indicate that European courts might take over this role); see also Seth Davis \& Christopher A. Whytock, 98 B.U. L. REV. 397, 400-01 (2018) (stating that "[w]ith the door closing on ATS suits in federal courts, attention is turning to suits asserting human rights claims in state courts based on state or foreign tort law or international law, and in federal courts based on state tort law").

11. Kiobel, 569 U.S. at 108.

12. Id. at 124 (illustrating that in absence of such close connection to the territory of the United States, the Court held, "the presumption against extraterritoriality applies to claims under the ATS").

13. See Milena Sterio, Corporate Liability for Human Rights Violations: The Future of the Alien Tort Claims Act, 50 CASE W. RES. J. INT'L L. 127, 149 (2018) (speculating in an article predating the Supreme Court decision that "the Court will more likely rule in favor of the plaintiffs/petitioners"); Ambassador David Scheffer, Is the Presumption of Corporate Impunity Dead?, 50 CASE W. RES. J. INT'L L. 213, 215 (2018) (doubting that the Supreme Court would "invoke[] the presumption against extraterritorial application of U.S. law in favor of Arab Bank... because the Supreme Court presumably granted certiorari only for the purpose of addressing the issue of corporate liability").

14. Goodyear Dunlop Tires Operations, S.A. v. Brown, 564 U.S. 915 (2011).

15. Daimler AG v. Bauman, 571 U.S. 117 (2014).

16. Bristol-Myers Squibb Co. v. Superior Court, 137 S. Ct. 1773 (2017). 
for alleged human rights violations involving its Argentinian subsidiary. ${ }^{17}$ While Kiobel and Jesner focused on the ATS, the court in Daimler did not even problematize ATS jurisdiction. It decided the case based on the lack of personal jurisdiction over foreign defendant Daimler. Personal jurisdiction, surprisingly, was not at issue during the Jesner litigation. However, in both Daimler and Jesner, the Court expressed strong concern for the sovereignty rights of foreign states. ${ }^{18}$ Jesner confirms a trend towards more judicial reticence already underlying its reasoning in Daimler. ${ }^{19}$ In this regard, both decisions suggest an increasing convergence of U.S. and foreign attitudes towards judicial discretion as well as personal jurisdiction rules. ${ }^{20}$ This consideration for foreign interests may seem like a positive development from an international perspective. However, all three decisions taken together lead to significant jurisdictional and substantive gaps in the ability of victims to hold multi-national corporations (MNCs) civilly liable for violations of international human rights for as long as the legislator does not take over the task of filling in the blanks left by the Supreme Court's restrictions. $^{21}$ This result seems paradoxical in an era of growing international concern for corporate entanglement in human rights abuses and multiplying public and private initiatives, including regulation and successful litigation to hold MNCs accountable - including in some of the countries whose governments have previously condemned the long arm of

17. See Daimler, 571 U.S. at 120 ("The complaint alleged that during Argentina's 19761983 'Dirty War,' Daimler's Argentinian subsidiary, Mercedes-Benz Argentina (MB Argentina) collaborated with state security forces to kidnap, detain, torture, and kill certain MB Argentina workers, among them, plaintiffs or persons closely related to plaintiffs.").

18. Concern about intrusion into foreign affairs was already a leitmotif in the Court's previous ATS opinions. See Kiobel v. Royal Dutch Petroleum Co., 569 U.S. 108, 116-17 (2013) (citing Sosa v. Alvarez-Machain, 542 U.S. 692, 727-28 (2004)) (explaining that ATS is strictly jurisdictional); see also Daimler, 571 U.S. at 142 (justifying limitations on personal jurisdiction by "[c]onsiderations of international rapport").

19. See Daimler, 571 U.S. at 141-42 (referring to the more limited approach to personal jurisdiction in the European Union); see also Patrick J. Borchers, The Twilight of the Minimum Contacts Test, 11 Seton Hall Cir. Rev. 1, 32 (2014) (noting that in recent decisions on personal jurisdiction "the Court continues to attempt to make policy judgments better handled by legislation than episodic bursts of confusing jurisdictional opinions").

20. See Gerlinde Berger-Walliser, Reconciling Transnational Jurisdiction: A Comparative Approach to Personal Jurisdiction over Foreign Corporate Defendants in US Courts, 51 Vand. J. Transnat'L L. 1243, 1290 (2018) (analyzing Daimler and pointing towards the remaining differences between US and European rules).

21. See Patrick J. Borchers, The Twilight of the Minimum Contacts Test, 11 Seton Hall Cir. Rev. 1, 32 (2014) (noting that in recent decisions on personal jurisdiction "the Court continues to attempt to make policy judgments better handled by legislation than episodic bursts of confusing jurisdictional opinions"). 


\section{U.S. ATS jurisdiction. ${ }^{22}$}

This article examines the growing role of human rights in corporate social responsibility, international and domestic regulation, and civil litigation. It does not attempt to establish whether Jesner was decided correctly, nor does it develop a new system of substantive rules to hold MNCs accountable for human rights abuses, which have been expertly discussed elsewhere. ${ }^{23}$ The article focuses on the international jurisdictional and choice of law issues, which civil complaints against foreign MNCs entail in a post-Jesner world. This topic has received far less attention than the appropriate legal basis for substantive claims. However, the place of the litigation as well as the rules determining the applicable law, commonly jointly referred to as private international law, have a direct impact on the outcome of private human rights cases. ${ }^{24}$ Therefore, the success of a

22. See supra note 9 (listing objections to extraterritorial application of the ATS by national governments); see also infra Part I(A). The most prominent example of a noncompulsory measure with global reach is probably the Guiding Principles on Business and Human Rights, endorsed by the United Nations Human Rights Council in 2011. See Human Rights Council Res. 17/4, U.N. Doc. A/HRC/RES/17/4, at 2 (July 6, 2011) (endorsing the Guiding Principles on Business and Human Rights: Implementing the United Nations "Protect, Respect and Remedy" Framework, in U.N. Doc. A/HRC/17/31 (Mar. 21, 2011)).

23. See, e.g., Robert C. Bird, Daniel R. Cahoy, \& Lucien J. Dhooge, Corporate Voluntarism and Liability for Human Rights in the Post-Kiobel World, 102 KY. L.J. 601, 642 (2013) (suggesting a private right of action based on a corporation's false, voluntary statements); see also Seth Davis \& Christopher A. Whytock, supra note 6, at 400 n.11 ("arguing that 'demise of ATS will signal rise of transnational tort litigation' of human rights claims") (citing Roger P. Alford, Human Rights After Kiobel: Choice of Law and the Rise of Transnational Tort Litigation, 63 EMORY L.J. 1089, 1091 (2014)); Donald Earl Childress III, The Alien Tort Statute, Federalism, and the Next Wave of Transnational Litigation, 100 GEO. L.J. 709, 715 (2012) (arguing that human rights claimants will increasingly rely on state and foreign law); Anna Maria Gabrielidis, Human Rights Begin at Home: A Policy Analysis of Litigating International Human Rights in U.S. State Courts, 12 Buff. Hum. RTS. L. Rev. 139, 179-84 (2006); Marco Simons, Keynote Address, Kiobel v. Royal Dutch Petroleum: A Practitioner's Viewpoint, 28 MD. J. INT'L L. 28, 41 (2013) (mentioning that "there is still no likelihood that transnational human rights litigation is going away anytime soon - the state courts remain open to transnational lawsuits for transitory torts"); Beth Stephens, State Law Claims: The Next Phase of Human Rights Litigation, 108 Am. Soc'y INT'L L. PROC. 442, 442 (2014) (stating that "victims of human rights abuses [after Kiobel] will increasingly file their claims in state courts"); Christopher A. Whytock, Donald Earl Childress III \& Michael D. Ramsey, After Kiobel—International Human Rights Litigation in State Courts and Under State Law, 3 U.C. IRvine L. REV. 1, 5 (2013) (arguing that "plaintiffs alleging human rights violations are increasingly likely to consider pursuing their claims in state courts or under state law"); Svetlana Meyerzen Nagiel, An Overlooked Gateway to Victim Compensation: How States Can Provide a Forum for Human Rights Claims, 46 Colum. J. Transnat'L L. 133, 133 (2007) (advocating "state statutory and common law causes of action" as "viable alternatives" to ATS).

24. See Ekatarina Aristova, Tort Litigation against Transnational Corporations in the 
renovated legal framework to hold MNCs civilly liable largely depends on the underlying rules that govern domestic courts' jurisdiction and applicable law. ${ }^{25}$ This article finds that these rules, despite the Supreme Court's recurring consideration of other countries' laws, continue to diverge. ${ }^{26}$ At its current state, U.S. personal jurisdiction rules are more restrictive than, for example EU rules, and would hinder most cases against foreign corporations before U.S. courts. ${ }^{27}$ The differences between legal systems lead to protection gaps for victims of international human rights abuses. To assure effective assertion of private rights for plaintiffs, while respecting legitimate business and foreign governments' sovereignty interests, a harmonized regime needs to address jurisdiction, applicable law, as well as substantive rules. However, since the Court clearly stated that the ATS is a jurisdictional - not substantive-statute, rather than closing the door on corporate liability for human rights violations, the decision may offer new opportunities for courts and domestic and international legislators to develop a coherent system for international corporate human rights litigation outside the ATS framework.

The article proceeds as follows. Part I reviews the development and current state of the business and human rights debate and provides an overview of U.S. and international corporate human rights regulation and litigation. Part II situates the Jesner decision within recent Supreme Court precedent on U.S. courts' personal jurisdiction over foreign corporate defendants. Part III compares U.S. to EU personal jurisdiction rules and discusses their suitability to provide effective remedies for human rights victims while balancing competing private and public interests. Part IV concludes.

English Courts: The Challenge of Jurisdiction, 14 UtreChT L. Rev. 6, 21 (2018) (referring to the changing role of private international law in an era of globalization, which historically was value-neutral).

25. See $i d$. at 10 (arguing that "[t]he territorial focus of the adjudicative jurisdiction is often contrary to the transnational nature of the TNC's activities").

26. See Daimler AG v. Bauman, 571 U.S. 117, 141-42 (2014) (pointing to EU jurisdiction rules).

27. See id. at 152 (holding that general personal jurisdiction requires that the defendant's "affiliations with the State are so 'continuous and systematic' as to render [it] essentially at home in the forum State" (quoting Goodyear Dunlop Tires Operations, S.A. v. Brown, 564 U.S. 915, $919(2011)))$. 


\section{JESNER, CORPORATE SOCIAL RESPONSIBILITY AND HUMAN RIGHTS}

\section{A. The Current State of the Business and Human Rights Relationship}

1. Emergence and Development of the Business and Human Rights Debate

Corporate human rights abuses come in various forms: dangerous working conditions, forced or child labor, discrimination of certain groups of employees, oppression of trade unions or collective bargaining, environmental contamination, and limitations of property rights. ${ }^{28}$ However, traditionally, private actors were not subject to human rights. Respect and protection of human rights for long was primarily considered the government's task. ${ }^{29}$ International criminal and humanitarian law has been applied to individuals, for example with regard to terrorism, human trafficking or slave labor. ${ }^{30}$ Corporations, in contrast, were not only immune from criminal prosecution or civil liability for human rights violations, over the past decades, multinational corporations (MNCs) have systematically exploited local communities or taken advantage of, for example, lax labor or environmental laws to rationalize their operations in foreign countries.

Consequently, MNCs have been responsible for, inter alia, the death of thousands of workers due to unsafe working conditions. ${ }^{31}$ Their operations have contaminated, forced and sometimes violently relocated local communities. $^{32}$ Private enterprises allegedly have and continue to be complicit in human rights abuses committed by oppressive governments or

28. See David Weissbrodt, Business and Human Rights, 74 U. CIN. L. REV. 55, 57-58 (2005) (providing multiple examples of human rights violations).

29. See id. at 59 ("International law and human rights law have principally focused on protecting individuals from violations by governments.").

30. See id. at $60 \mathrm{n} .18$ (stating that "[t]he International Criminal Court has jurisdiction only over natural persons (including corporate officers), but not over legal persons, such as corporations").

31. See, e.g., Tansy Hoskins, Reliving the Rana Plaza Factory Collapse: A History of Cities in 50 Buildings, Day 22, The GuARDian (last visited Apr. 23, 2015), www.theguardian.com/cities/2015/apr/23/rana-plaza-factory-collapse-history-cities-50-build ings [https://perma.cc/HD8P-NUUY] (detailing the collapse of a building in Bangladesh).

32. See, e.g., Human Rights Watch, Whose Development? Human Rights Abuses in Sierra Leone's Mining Boom, Human Rights Watch (Feb. 19, 2014), https://www.hrw.org/ report/2014/02/19/whose-development/human-rights-abuses-sierra-leones-mining-boom [https://perma.cc/C59A-XB6S] (focusing on the human rights impact of mining activity at African Mineral Limited in Sierra Leone). 
paramilitary groups. ${ }^{33}$ Firms have benefitted from forced labor, such as German companies under the Nazi regime. ${ }^{34}$ They have facilitated brutal civil wars and atrocities, e.g. in the Democratic Republic of Congo, ${ }^{35}$ or the violent displacement, extrajudicial killing, and torture of civilians in Sudan. ${ }^{36}$

In light of globalization and the growing power of corporations, the traditional view that only states are accountable under human rights law, has been challenged. ${ }^{37}$ As a reaction to the atrocities committed during World War II, the United Nations was created in 1945 and the concept of international human rights emerged. ${ }^{38}$ The Nuremberg trials after World War II are frequently cited as the starting point for the so-called business and human rights debate, though they resulted in criminal punishment of individuals rather than the firms complicit in the atrocities of the Third Reich themselves. ${ }^{39}$ During the trials, Alfred Krupp, a German industrialist, as well as several of the company's officers were convicted, among others for the use of slave labor. Corporate officers at I.G. Farben, another German firm that played an important role in supporting the Nazi regime, were sentenced

33. See Schrempf-Stirling \& Wettstein, supra note 5, at 545 (providing multiple examples of human rights abuses committed by oppressive governments).

34. See generally Ulrich Herbert \& William TeMPLER, HitLer's Foreign Workers: ENFORCED Foreign Labor IN GERMANY UNDER THE THIRD REICH (2006) (detailing an instance of forced labor by foreign workers outside their own country).

35. United Nations ECONOMic COMmission fOR Africa, Conflicts in the DEMOCRATIC RePUBlic OF CONGO: CAUSES, IMPACT AND IMPLiCATIONS FOR THE GREAT LAKES REgion, United NATions 92 (Sept. 2015), www.uneca.org/sites/default/files/PublicationFile s/conflits_in_drc_eng_25sept_rev1.pdf [https://perma.cc/XY4G-VBKU].

36. See Schrempf-Stirling \& Wettstein, supra note 5, at 545 (addressing Talisman's involvement in Sudan and other examples of corporate complicity).

37. Peter T. Muchlinski, Human Rights and Multinationals: Is There a Problem?, 77 INT'L AFF., 31, 31 (2001) (attributing the shift to the "increasing integration of the global economy").

38. See Anna Triponel, Business \& Human Rights Law: Diverging Trends in the United States and France, 23 Am. U. INT'L. L. Rev. 855, 858 n.8 (2008) ("stating that the establishment of the U.N. Charter and the Nuremberg trials erased the notion that the protection of human rights 'lay within the exclusive jurisdiction of the sovereign state' instead of with the international community at large") (citing Douglass Cassel, Corporate Initiatives: A Second Human Rights Revolution?, 19 FoRdHAM InT'L L.J. 1963, 1963 (1996)).

39. See Brief of Ambassador David J. Scheffer, Northwestern University Pritzker School of Law, as Amicus Curiae in Support of the Petitioners at 16, Jesner v. Arab Bank, PLC, 138 S. Ct. 1386 (2018) ("There had been acknowledgement of corporate criminal liability in international law even at Nuremberg.") (citing David Scheffer \& Caroline Kaeb, The Five Levels of CSR Compliance: The Resiliency of Corporate Liability under The Alien Tort Statute and the Case for a Counterattack Strategy in Compliance Theory, 29 BERKELEY J. INT'L L. 334, 363 (2011)); see also Kiobel v. Royal Dutch Petroleum Co., 621 F.3d 111, 179-80 (2d Cir. 2010) (Leval, J., concurring) (describing the liability of IG Farben as a predicate for individual responsibility). 
to terms of imprisonment for forced labor, providing the poison gas used in concentration camps, and other crimes. ${ }^{40}$ In modern days, corporate officers have been criminally charged for human rights violations, such as Dutch business man Frans van Anraat, who in 2007 was convicted of complicity in war crimes for the supply of chemicals used in the chemical weapon's program of Saddam Hussein in Iraq. ${ }^{41}$ Currently, Amesys - a subsidiary of Bull-employees are on trial before a French court for providing surveillance equipment to the Gaddafi government in Libya in $2007 .{ }^{42}$

In the 1990's, non-governmental organizations (NGOs) such as Human Rights Watch and Amnesty International, and more recently, the Business \& Human Rights Resource Centre, ${ }^{43}$ started exposing and protesting the human rights abuses of U.S. and foreign companies. ${ }^{44}$ Besides raising public awareness and inflicting reputational damage, NGOs have since been effective in influencing public policy and initiating numerous, though compared to the number of abuses isolated, civil and criminal lawsuits. ${ }^{45}$ Additionally, on the academic side, serious thought started being invested in business and human rights in the late 1980's and 1990's. The two main questions that arose from these debates concerned both fairness and justice. They can be summarized as follows: (1) "On what foundation do businesses owe moral duties to anyone regarding human rights?"46 (2) "How extensive

40. See generally Stanley A. Goldman, A Fuhrer of Industry: Krupp Before, During and After Nuremberg, 39 Loy. L.A. INT'L \& COMP. L. REV. 187 (2017) (recounting Krupp history); see also United States Military Tribunal at Nuremburg - United States v. Alfried Krupp et al., rpt. in 10 LAW RePORTS OF TRIALS OF WAR CRIMINALS 130, THE U.N. WAR CRIMES COMMISSION 130-59 (1949), https://casebook.icrc.org/case-study/united-states-milit ary-tribunal-nuremberg-united-states-v-alfried-krupp-et-al [https://perma.cc/S6XV-XZEG] (summarizing the course of the most consequential proceedings taken against persons accused of committing war crimes during World War II).

41. See Public Prosecutor v. Frans Cornelis Adrianus van Anraat, InTERnATIOnAL CRIMES DATABASE (ICD), http://www.internationalcrimesdatabase.org/Case/168/VanAnraat/ [https://perma.cc/M9CY-YZTA] (outlining the procedural history and decision by the Court of Appeal of The Hague, The Netherlands).

42. See Amesys lawsuit (re Lybia), Business and Human Rights Resource Centre (last visited Apr. 21, 2019), https://www.business-humanrights.org/en/amesys-lawsuit-re-lib ya-0 [https://perma.cc/49ZL-V45Z] (providing a summary of Amesys lawsuit).

43. Business \& Human Rights Resource CEnTER, https://www.business-humanrights. org/en [https://perma.cc/HTM4-VVX7] (last visited Apr. 21, 2019).

44. James Paul, Global Policy Forum: The Power Shift and the NGO Credibility Crisis, INT'L J. NOT-FOR-PROFIT L. (2006), www.globalpolicy.org/component/content/article/176/3 1423.html [https://perma.cc/5V3T-PWTF].

45. Lina Marcinkute, The Role of Human Rights NGO's: Human Rights Defenders or State Sovereignty Destroyers?, 4 Baltic J. L. \& POL. 55 (2011).

46. Thomas Donaldson, The Ethics of International Business 49 (1989); see also John J. Keller, Multinational Business and Human Rights, 88 Am. SoC'Y INT'L L. Proc. 271, 
are the human rights duties of business in situations where business has no direct or indirect connection to human rights violations?" 47 Hence, the debate over business's accountability for human rights evolved from an international criminal law matter to an issue of corporate social responsibility (CSR) and civil liability, and the debate, as the following section will illustrate, is far from being settled.

\section{Corporate Embrace of Business and Human Rights}

Beyond NGO activism, international conventions, and academic writing, there have been some broader trends pushing for business and human rights. ${ }^{48}$ On the one hand, advances in information technology over the past thirty years illuminate previously obfuscated regions and have led to a shift in consumer and investor awareness that explains their increasing preference for moral action. $^{49}$ On the other hand, the increasing wealth, power, and influence of MNCs over state actors puts them in a position to not only protect but also to promote human rights. ${ }^{50}$ These trends, and more, are slowly causing businesses to change their underlying moral framework away from shareholder primacy or utilitarian business models towards stakeholder engagement and CSR. ${ }^{51}$ However, there have been several issues that have slowed down businesses' adoption of human rights and that explain why, even today, establishing a consensus about business and human rights that includes corporations remains elusive. This may be because CSR

271-72 (1994) (questioning "what obligations do corporations have in the face both of host country human rights violations and of their need to pursue low-wage environments and rapidly expanding markets?").

47. Michael A. Santoro, Business and Human Rights in Historical Perspective, $14 \mathrm{~J}$. HuM. RTS. 155, 155-56 (2015).

48. See infra Part I(A)(2) (describing international conventions in greater detail).

49. See Business and Human Rights: A Progress Report, OCHR.ORG (2000), https://ww w.ohchr.org/Documents/Publications/BusinessHRen.pdf [https://perma.cc/N3WQ-LQQM] (explaining that human rights are a key performance indicator for corporations throughout the world).

50. See Alfred D. Chandler \& Bruce Mazlish, Leviathans: Multinational CORPORATIONS AND THE NEW Global History 136-39 (2005) (comparing nations and MNCs economic power); see also Anna Triponel, Business \& Human Rights Law: Diverging Trends in the United States and France, 23 AM. U. INT'L L. REV. 855, 860 (2008) (internal citations omitted) ("The dramatic increase in corporations' wealth, power, influence and responsibility over the last twenty years explains why corporations, especially transnational corporations ('TNCs'), are increasingly expected to respect human rights law directly.').

51. See Archie B. Carroll, The Pyramid of Corporate Social Responsibility: Toward the Moral Management of Organizational Stakeholders, 34 Bus. HoRIzons 39, 40 (1991) (describing the shift from social responsibility, over social responsiveness, to corporate social performance). 
generally focuses on the positive impact a corporation has on society, whereas human rights mainly focus on negative impact. ${ }^{52}$ One reason why many firms have been slow to adopt human rights is that they are already preoccupied with their other CSR initiatives. Because many corporations already are pursuing CSR actions, they may see human rights norms as a challenge to their existing CSR programs. Even though human rights have more recently been regarded as complementary to CSR, the preference of focusing on other forms of CSR remains. ${ }^{53}$ No customer or investor will be impressed that a company is not violating human rights, as this would be the underlying expectation, while a CSR program that builds on positive impact can create value for the business through a favorable image. ${ }^{54}$

Another reason business is reluctant to accept responsibility for human rights is the evolving nature of those rights and the reach of responsibility of human rights obligations. The United Nations and human rights advocates have made clear that even if a company does not violate human rights themselves, they should be accountable for their entire supply chain. ${ }^{55}$ Additionally, there has been a trend in the human rights debate to call for the proactive protection of human rights like a living wage and gender equality, which are not easily definable. ${ }^{56}$ Businesses worry that if they accept one

52. See id. at 751 ("[W]hile CSR has lacked a constitutive focus on people's rights, the business and human rights debate has lacked the focus on the positive potential of corporations to be a part of the solution rather than only a part of the problem.").

53. See Florian Wettstein, CSR and the Debate on Business and Human Rights: Bridging the Great Divide, 22 Bus. ETHICs Q. 747 (2012) (pointing towards the UN Guiding Principles as the starting point for this shift in perception).

54. See generally Michael E. Porter \& Mark R. Kramer, Creating Shared Value: How to Reinvent Capitalism - and Unleash a Wave of Innovation and Growth, 89 HARV. Bus. REV. 62 (2011) (describing companies being widely perceived as prospering at the expense of the broader community, and being blamed for society's failures even when they begin to embrace corporate responsibility).

55. See Michael A. Santoro, Business and Human Rights in Historical Perspective, $14 \mathrm{~J}$. HuM. RTS., 155, 155 (2015) (noting that human rights activists advocate for an additional duty to help "prevent and remedy human rights violations committed by others"); see also James G. Stewart, Complicity in Business and Human Rights, 109 Proc. Ann. MeETing, Am. Soc'Y INT'L L. 181-84 (2015) (explaining that international law needs to reevaluate its stance towards issues of complicity given that there has been a shift from direct violations of international law precepts to the ways in which individuals, businesses, and states will increasingly be complicit in international law violations); see generally Human Rights in Supply Chains: A Call for a Binding Global Standard on Due Diligence, Human Rights WATCH (May 30, 2016), https://www.hrw.org/report/2016/05/30/human-rights-supply-chain s/call-binding-global-standard-due-diligence\# [https://perma.cc/V684-K29V] (stating that despite complex global supply chains being capable of offering important opportunities for economic and social development, they can also present serious human rights risks that many companies have failed to mitigate and respond to effectively).

56. See '4 In 10 Companies 'Failing' on Human Rights,' World Benchmarking 
definition of these rights they may end up accepting a much more onerous version later on. For example, a living wage has many definitions: what would pass as a living wage in Indonesia or India may seem like a human rights abuse in the United States or France. ${ }^{57}$ Therefore, the risk of making a commitment to a living wage may add a range of costs, which is why most businesses opt for the strategy of local market value for labor. ${ }^{58}$

For the aforementioned reasons, companies still do not see compliance with human rights as a net positive like many now consider CSR programs. This being said, many businesses still do not yet consider even tame CSR programs to be a net positive and will not change their current practices. This underscores the continued need for international collaboration to create a direct obligation for companies to respect and promote human rights through regulation and other legal means. In this regard, while much remains to be done, and despite the latest setbacks in Kiobel and Jesner, the business and human rights agenda has made great strides forward on the international level, as well as on the regional and national levels. These regulatory efforts will be discussed in the next section.

\section{Business and Human Rights Regulation}

On the international level, soft law mechanisms have been employed to regulate the conduct of MNCs and international business activities. Prominent examples include the Organisation for Economic Co-operation and Development's (OECD's) Guidelines for Multinational Enterprises, ${ }^{59}$ the International Labor Organization's (ILO's) Tripartite Declaration of

ALLIANCE (Nov. 19, 2018), www.worldbenchmarkingalliance.org/4-in-10-companies-failing -on-human-rights/[https://perma.cc/ZFQ8-7DDK] (stating "virtually no companies demonstrate strong commitments to ensuring living wages are paid to workers in their own operations and supply chains.").

57. See Wages in Context, WAGEINDICATOR.ORG (2019), https://wageindicator.org/salar y/wages-in-context [https://perma.cc/L97Z-C7JP] (noting that the highest living wage countries have a living wage 10 times or more than that of the lowest).

58. See Alexander Hijzen and Paul Swaim, Do Multinationals Promote Better Pay and Working Conditions?, OECD OBSERVER (Oct. 2008), oecdobserver.org/news/archivestory.p hp/aid/2767/Do_multinationals_promote_better_pay_and_working_conditions_.html [https:/ /perma.cc/L5D7-XQPV] (explaining that the effect multinationals have on wages and working conditions can be positive, but there are conditions which policymakers wishing to attract foreign direct investment should keep in mind).

59. Report of the Committee on International Investment and Multinational Enterprises on the Review of the 1976 Declaration and Decisions, 18 I.L.M. 986 (1979). The OECD updated these Guidelines in 2000. OECD GUIDELINES FOR MULTINATIONAL ENTERPRISES (2000), http://www.oecd.org/dataoecd/56/36/1922428.pdf [https://perma.cc/Y3WY-S7C5]. 
Principles Concerning Multinational Enterprises, ${ }^{60}$ the United Nations Norms on the Responsibilities of Transnational Corporations, ${ }^{61}$ the United Nations Global Compact, ${ }^{62}$ and, most prominently, the Guiding Principles for Business and Human Rights. ${ }^{63}$ The principles provide the so-called protect, respect, and remedy framework for human rights. They lay out specific obligations, processes, and ways of implementations that companies are expected to adopt to pursue the respect of human rights. ${ }^{64}$ These proposals for pragmatic implementation distinguish the Guiding Principles from other international soft law. ${ }^{65}$ Additionally, the United Nations encourages countries to develop and enact national action plans (NAP's) to implement the Guiding Principle's framework, ${ }^{66}$ though the first examples of implementation have received mixed approval from the human rights community. ${ }^{67}$ Additionally, an inter-governmental working group established by the U.N. Human Rights Council is currently elaborating "an international legally binding instrument to regulate, in international human rights law, the activities of transnational corporations and other business enterprises." ${ }^{, 68}$

On the regional or national level, governments have taken action to hold

60. International Labour Organisation, Tripartite Declaration of Principles concerning Multinational Enterprises and Social Policy, 17 I.L.M. 422, 6 (1978), http://www.ilo.org/pu blic/english/employment/multi/index.htm [https://perma.cc/9R4B-YCJ3].

61. Comm. on Human Rights, Subcomm. on the Promotion \& Prot. of Human Rights, Rep. on its 55th Sess. (Aug. 13, 2003), Economic, Social and Cultural Rights: Norms on the Responsibilities of Transnational Corporations and Other Business Enterprises with Regard to Human Rights, U.N. Doc. (Aug. 26, 2003), E/CN.4/Sub.2/2003/12/Rev.2.

62. About the UN Global Compact, United Nations Global Compact, http://www. unglobalcompact.org/AboutTheGC/index.html [https://perma.cc/G9NG-WTTG] (last visited Nov. 13, 2018).

63. Guiding Principles on Business and Human Rights: Implementing the United Nations "Protect, Respect and Remedy" Framework, United Nations Human Rights OfFICE OF THE High COMMISSIONER (2011), https://www.ohchr.org/Documents/Publications/ GuidingPrinciplesBusinessHR_EN.pdf [https://perma.cc/GDB5-N2MY].

64. See Bird, Cahoy \& Dhooge, supra note 23, at 622 ("'The principles] present specific obligations, processes, and implementations that firms are expected to pursue in respecting human rights.").

65. See id. (describing Ruggie's "principled pragmatism” approach).

66. See State National Action Plans on Business and Human Rights, United Nations Human Rights, OfFice OF THE High COMmissioner, https://www.ohchr.org/en/iss ues/business/pages/nationalactionplans.aspx [https://perma.cc/S9WD-DPXD] (providing a list of countries that have produced a NAP).

67. Cindy Woods, Assessments of Existing National Action Plans (NAPs) on Business and Human Rights, InTERnational Corporate AcCountability Roundtable (Aug. 23, 2017), www.icar.ngo/publications/2017/8/23/assessments-of-existing-national-action-plansnaps-on-business-and-human-rights-august-2017 [https://perma.cc/DY7M-XQ6F].

68. Human Rights Council Res. 26/9, U.N. Doc. A/HRC/RES/26/9, at 2 (July 14, 2014). 
businesses accountable for their international human rights impacts through mandatory reporting. The 2010 Dodd-Frank Wall Street Reform and Consumer Protection Act includes a provision requiring corporations to disclose the use of "conflict minerals" in products manufactured by covered entities. ${ }^{69}$ Despite criticism and limited success of the U.S. conflict minerals regulation, ${ }^{70}$ the European Union has followed the U.S. example and in 2017 enacted the EU conflict minerals regulation. ${ }^{71}$ Additionally, the $2014 \mathrm{EU}$ directive on non-financial disclosure requires companies incorporated in member states "to disclose in their management report relevant and material information on policies, outcomes and risks, including due diligence that they implement, and relevant non-financial key performance indicators concerning environmental aspects, social and employee-related matters, respect for human rights, anti-corruption and bribery issues, and diversity on the boards of directors." "72 Individual Member States, including the U.K., Sweden, Denmark, France, and Spain have their own non-financial disclosure policies as well, which include mandatory reporting on human rights policies and programs. ${ }^{73}$

In 2015, the United Kingdom enacted the Modern Slavery Act. ${ }^{74}$ In its final version, the act compels large corporations to publish a statement about how they are preventing slavery in their supply chain. ${ }^{75}$ These reports are published online for anyone to see with the intent of increasing social pressure on firms who report lackluster anti-slavery due diligence. ${ }^{76}$ Most

69. 15 U.S.C. $§ 78 \mathrm{~m}(\mathrm{p})$ (2012); Karen E. Woody, Conflict Minerals Legislation: The SEC's New Role as Diplomatic and Humanitarian Watchdog, 81 FordHAM L. Rev. 1315, 1316 (2012); Marcia Narine, Disclosing Disclosure's Defects: Addressing Corporate Social Irresponsibility for Human Rights Impacts, 47 Colum. Hum. RTs. L. Rev. 84 (2015).

70. The regulation has been criticized for its unintended consequences, i.e. in an effort to avoid reporting obligations, companies simply refrain from sourcing in the listed countries thereby hurting their already fragile economies. See Woody, supra note 69, at 1346 (arguing that the reporting requirements are likely to lead to a "de facto embargo").

71. Regulation (EU) 2017/821 of the European Parliament and of the Council of 17 May 2017, 2017 O.J. (L 130/1) (listing "supply chain due diligence obligations for Union importers of tin, tantalum and tungsten, their ores, and gold originating from conflict-affected and highrisk areas").

72. European Commission Memorandum, Disclosure of Non-Financial and Diversity Information by Large Companies and Groups - Frequently Asked Questions, EuROPEAN Commission (Apr. 5, 2014), http://europa.eu/rapid/press-releaseMEMO-14-301en.htm [http s://perma.cc/YDX3-L8A7].

73. $I d$.

74. MODERN SLAVERY ACT OF 2015, § 54, http://www.legislation.gov.uk/ukpga/2015/30 /contents/enacted [https://perma.cc/8WKD-VTBJ].

75. Id. at $\S 54(1)$.

76. See TISC Report Modern Slavery Act Compliance Tracker, https://tiscreport.o rg (tracking companies which comply with the TISCreport Modern Slavery Act). 
recently, the French legislator, in probably the most far-reaching regulatory effort thus far, has enacted a law that obliges French companies with 5,000 or more employees to monitor subsidiaries and suppliers to prevent grave violations of human rights, basic liberties, health, safety, and environmental risk. $^{77}$ Similar mandatory human rights due diligence laws are under discussion in various European countries and Canada. ${ }^{78}$

In the United States, regulation concerned with business and human rights has centered on mandatory disclosure. At the federal level (besides Dodd Frank Act section 1502 on conflict minerals), mandatory corporate human rights reporting has emerged around specific issues, such as forced labor, human trafficking, and specific geographical zones. ${ }^{79}$ These reporting obligations have compelled companies to publish information on their policies and processes, including those intended to prevent and mitigate violations of human rights in connection with new investments in certain countries. ${ }^{80}$ Proposed legislation for more comprehensive human rights reporting has been introduced to the United States Congress as an amendment to the "Securities Exchange Act of 1934 to require certain companies to disclose information describing any measures the company has taken to identify and address conditions of forced labor, slavery, human trafficking, and the worst forms of child labor within the company's supply chains." 81

77. Assemblée Nationale, Proposition de loi RElative AU DEVOIR DE VIGILANCE DES SOCIETES MERES ET DES ENTREPRISES DONNEUSES D'ORDRE (Feb. 21, 2017), http://www.assem blee-nationale.fr/14/ta/ta0924.asp [https://perma.cc/Q79Y-8L23]; see also Gerlinde BergerWalliser \& Inara Scott, Redefining Corporate Social Responsibility in an Era of Globalization and Regulatory Hardening, 55 AM. Bus. L.J. 167, 206 (2018) ("This law, which goes beyond disclosure to a substantive monitoring obligation, may represent a significant shift in policy to make companies more directly responsible for the activities of their suppliers.").

78. See generally The Rise of Mandatory Human Rights Due Diligence in the Supply Chain, ECOVADIS, http:/www.ecovadis.com/library/human-rights-due-diligence/\#download [https://perma.cc/RR7C-QAES] (providing ethical insights of global supply chains).

79. Anthony Ewing, MANDATORY Human Rights REPORTING (2015), https://logoscons ulting.net/mandatory-human-rights-reporting/ [https://perma.cc/33HD-N49Y].

80. See, e.g., Office of Foreign Assets Control, U.S. DePARTMENT OF THE TrEasury, htt ps://www.treasury.gov/about/organizational-structure/offices/pages/office-of-foreign-assetscontrol.aspx [https://perma.cc/2VLC-3Q4R] (2013) (outlining the role of the Office of Foreign Assets Control of the US Department of the Treasury); 2016 Consultation on Renewing the U.S. Reporting Requirements on Responsible Investment in Burma/Myanmar, INSTITUTE FOR HUMAN RigHTS AND BusinESS (Jan. 25, 2016), https://www.ihrb.org/focus-are as/myanmar/submission-reporting-requirements-responsible-investment-myanmar-2016 [htt ps://perma.cc/UNV4-ZMKG] (describing reporting requirements for certain U.S. investments in Myanmar).

81. Business Supply Chain Transparency on Trafficking and Slavery Act of 2018, H.R. 7089, 115th Cong. (2018), https://www.congress.gov/bill/115th-congress/house-bill/7089 
Besides the California Transparency in Supply Chains Act of 2010 (SB 657 ) on human trafficking, there is no state-level legislation specifically addressing corporate accountability for human rights. Hence, private litigation against corporate defendants in the United States primarily has been based on the ATS. The next section outlines U.S. courts' ATS jurisprudence prior to Jesner. The following section summarizes that decision.

\section{B. Human Rights and ATS Litigation in the United States}

Although a comprehensive review of human rights litigation against corporations in the United States is beyond the scope of this article, an overview of how private litigation evolved in this respect is necessary to place Jesner in proper perspective. Because corporations as private entities typically cannot be sued before international tribunals, enforcement of direct corporate human rights liability is generally left to domestic courts. ${ }^{82}$

In the United States, the primary vehicle for holding corporations civilly liable for their involvement in international human rights violations is the ATS. $^{83}$ The ATS is a unique statute, unparalleled in both domestic and international legislation. For long, commentators and courts have pointed to difficulties in interpreting the ATS because of a lack of legislative history. ${ }^{84}$ Justice Gorsuch, in his concurrence in Jesner, went as far as to suggest finally ending the "ATS exceptionalism.","

The ATS provides original jurisdiction to the district courts in cases

$? \mathrm{q}=\% 7 \mathrm{~B} \% 22$ search $\% 22 \% 3 \mathrm{~A} \% 5 \mathrm{~B} \% 22$ business + supply+chain + transparency $\% 22 \% 5 \mathrm{D} \% 7 \mathrm{D}$ $\& \mathrm{r}=1$ [https://perma.cc/KP9F-MWY8]. Prospects of the bill being enacted seem low given that earlier versions were previously introduced to both the House and the Senate in 2014 and 2015, but so far have been unsuccessful. H.R. 7089 (115 th $)$ : Business Supply Chain Transparency on Trafficking and Slavery Act of 2018, GovTRACK, https://www.govtrack.us /congress/bills/115/hr7089 [https://perma.cc/Z5AT-NPR6].

82. See Saman Zia-Zarifi, Suing Multinational Corporations in the U.S. for Violating International Law, 4 UCLA J. INT'L L. \& FoR. AFF. 81, 87 (1999) (stating "the legal status of MNCs under international law has not advanced significantly . . . since the International Court of Justice despaired of finding suitable international legal principles for addressing the litigation surrounding the Barcelona Traction company and simply decided that famous case on the basis of domestic laws.").

83. See Triponel, supra note 50, at 904-05 (noting that "the United States is not party to all international human rights agreements, and even when it is, the agreements need implementing legislation" and pointing towards the pioneering role of U.S. courts in using "civil remedies to sue human rights violators under the Alien Torts Claim Act [ATCA]").

84. See Bird, Cahoy \& Dhooge, supra note 23, at 604 (referencing multiple court decisions that have commented on the difficulties of interpreting the ATS).

85. Jesner v. Arab Bank, PLC, 138 S. Ct. 1386, 1412 (2018) (Gorsuch, J., concurring). 
where an alien alleges "violation of the law of nations or a treaty of the United States." 86 The ATS was enacted by the First Congress in 1789 but laid largely dormant until it was resurrected by the Second Circuit in Filartiga to allow the heirs of an alleged Paraguayan torture victim to sue a Paraguayan police officer living in New York. ${ }^{87}$ In the wake of this decision, Congress enacted the Torture Victim Protection Act (TVPA), ${ }^{88}$ but made clear that the ATS should "remain intact to permit suits based on other norms that already exist or may ripen in the future into rules of customary international law." ${ }^{89}$ It remained unclear, however, what type of torts fit those standards beyond the historical cases Congress had in mind when enacting the ATS, namely "interference with ambassadors, and piracy." "In yet another prominent decision, the Second Circuit, in Kadic v. Karadzic" held that the ATS could be used against private individuals. ${ }^{92}$ What followed was the first series of ATS cases against corporate defendants before federal courts. ${ }^{93}$ Against this background, the Supreme Court in its 2004 decision in

86. 28 U.S.C. $\S 1350$.

87. See Filartiga v. Pena-Irala, 630 F.2d 876 (2d Cir. 1980) (holding that the Alien Tort Statute provides federal jurisdiction whenever an alleged torturer is found and served with process by an alien within U.S. borders).

88. 28 U.S.C. $\$ 1350$.

89. Sosa v. Alvarez-Machain, 542 U.S. 692, 728 (2004) (citing H.R. REP. No. 102-367, pt. 1, at $4(1991))$.

90. See Jesner, 138 S. Ct. at 1392 (Gorsuch, J., concurring) (citing Sosa, 542 U.S. at 715 (2004)).

91. 70 F.3d 232, 239 (2d Cir. 1995) ("[W]e do not agree that the law of nations, as understood in the modern era, confines its reach to state action. Instead, we hold that certain forms of conduct violate the law of nations whether undertaken by those acting under the auspices of a state or only as private individuals.").

92. See Zia-Zarifi, supra note 82 (citing Beth Stephens, Conceptualizing Violence Under International Law: Do Tort Remedies Fit the Crime?, 60 ALB. L. Rev. 579, 594 (1997)) (noting that the application of international norms against non-State actors is the most problematic element of the ATS).

93. Though most of these cases, such as Wiwa v. Royal Dutch Petroleum Co., 226 F.3d 88, 92 (2d Cir. 2000), were dismissed on jurisdictional grounds, a high-profile case against Unocal for allegedly benefitting from forced labor and other human rights violations during its Yadana gas pipeline construction project in Burma was settled. See Doe v. Unocal Corp., 963 F. Supp. 880, 883 (C.D. Cal. 1997) ("Plaintiffs seek injunctive, declaratory and compensatory relief for alleged international human rights violations perpetrated by defendants Unocal, Total and MOGE's joint venture, the Yadana gas pipeline project."). See Schrempf-Stirling \& Wettstein, supra note 5, at 550-54, for an overview of U.S. and international human rights related foreign direct liability cases and their outcome. The authors find "[t]o date, with the recent exception of Shell's Nigerian subsidiary's conviction by a court in the Netherlands in January 2014, no company has been found guilty of human rights violations in a foreign direct liability case." Schrempf-Stirling \& Wettstein, supra note 5, at 546. However, their study suggests that there might be other positive effects of human rights litigation "despite this modest judicial success." Schrempf-Stirling \& Wettstein, supra note 
Sosa v. Alvarez-Machain sought to give some guidance to lower courts. ${ }^{94}$

In Sosa, the Supreme Court recognized serious separation-of-powers and foreign relations concerns that call for "judicial restraint" in ATS litigation. ${ }^{95}$ The Court held that "federal courts should not recognize private claims under federal common law for violations of any international law norm with less definite content and acceptance among civilized nations than the historical paradigms familiar when $\S 1350$ was enacted." 96 However, Justice Souter, writing for the majority, also acknowledged that the ATS under certain narrow circumstances allowed for recognition of new classes of international norms. ${ }^{97}$ This lead to a two-step test to determine if a norm qualifies for purposes of international law under the ATS, later used inter alia in Jesner: (1) A plaintiff must show that the alleged action in violation of international law is "of a norm that is specific, universal, and obligatory." 98 (2) If there is a specific norm controlling, it must be "determined further whether allowing this case to proceed under the ATS is a proper exercise of judicial discretion, or instead whether caution requires the political branches to grant specific authority before corporate liability can be imposed." 99 Finally, the Court noted that the "determination whether a norm is sufficiently definite to support a cause of action should (and, indeed, inevitably must) involve an element of judgment about the practical

5 , at 546.

94. See generally Sosa, 542 U.S. at 694 ("The ATS is a jurisdictional statute creating no new causes of action. This does not mean, as Sosa contends, that the ATS was stillborn because any claim for relief required a further statute expressly authorizing adoption of causes of action. Rather, the reasonable inference from history and practice is that the ATS was intended to have practical effect the moment it became law, on the understanding that the common law would provide a cause of action for the modest number of international law violations thought to carry personal liability at the time: offenses against ambassadors, violation of safe conducts, and piracy.").

95. Id. at 725 ("There are good reasons for a restrained conception of the discretion a federal court should exercise in considering a new cause of action of this kind. Accordingly, we think courts should require any claim based on the present-day law of nations to rest on a norm of international character accepted by the civilized world and defined with a specificity comparable to the features of the 18th-century paradigms we have recognized."). See also id. at 727 ("It is one thing for American courts to enforce constitutional limits on our own State and Federal Governments' power, but quite another to consider suits under rules that would go so far as to claim a limit on the power of foreign governments over their own citizens, and to hold that a foreign government or its agent has transgressed those limits.").

96. Id. at 732 .

97. See id. at 729 (noting that "[j]udicial power should be exercised on the understanding that the door is still ajar subject to vigilant doorkeeping, and thus open to a narrow class of international norms today").

98. Id. at 732 .

99. Jesner v. Arab Bank, PLC, 138 S. Ct. 1386, 1399 (2018). 
consequences of making that cause available to litigants in the federal courts." ${ }^{100}$ The latter include, for example, exhaustion of remedies in the plaintiff's home state, or political questions better decided by the executive branch. ${ }^{101}$ The question whether "international law extends the scope of liability for a violation of a given norm to the perpetrator being sued, if the defendant is a private actor such as a corporation or individual," at issue in Kadic and a conflicting lower court decision in Tel-Oren v. Libyan Arab Republic, ${ }^{102}$ was left unanswered. ${ }^{103}$

The later issue was raised, but was ultimately not decided in Kiobel, the second ATS case before the Supreme Court. After hearing oral arguments, the Court changed the legal issue it originally had granted certiorari for and answered the question "[w] hether and under what circumstances the [ATCA] allows courts to recognize a cause of action for violations of the law of nations occurring within the territory of a sovereign other than the United States" instead. ${ }^{104}$ The Court held that recognized "principles underlying the presumption against extraterritoriality ... constrain courts exercising their power under the ATS" outside of the territory of the United States and that "nothing in the [ATS] rebuts that presumption." 105 The Court added, even where the "claims touch and concern the territory of the United States, they must do so with sufficient force to displace the presumption against extraterritorial application." 106

Besides the original question of corporate liability under the ATS, Kiobel left many questions open. For example, the Court did not address the precise contours of the territoriality requirement, ${ }^{107}$ nor "whether domestic or international law should apply to the issue of whether corporations can be sued under the [ATCA]?"108

100. Sosa, 542 U.S. at $732-33$.

101. See id. at 733 n.21 ("This requirement of clear definition is not meant to be the only principle limiting the availability of relief in the federal courts for violations of customary international law .... Another possible limitation that we need not apply here is a policy of case-specific deference to the political branches.").

102. Tel-Oren v. Libyan Arab Republic, 726 F.2d 774, 791-95 (C.A.D.C. 1984).

103. Sosa, 542 U.S. at 732 n.20.

104. Kiobel v. Royal Dutch Petroleum Co., 569 U.S. 108, 114 (2013). See also Sterio, supra note 13, at 136 ("By requesting parties to prepare briefs and arguments on the issue of whether a corporation may be sued under the ATCA for acts committed abroad (which may have violated the law of nations), the Supreme Court avoided directly addressing the issue of corporate liability under the [ATS].") (citing Michael Kelly, Atrocities by Corporate Actors: A Historical Perspective, 50 CASE W. Res. J. InT'L L. (2018)).

105. Kiobel, 569 U.S. at 117, 124.

106. Id. at 125 (citing Morrison v. Nat'l Austl. Bank Ltd., 561 U.S. 247, 264-73 (2010)).

107. Id. at 124-25.

108. Sterio, supra note 13, at 128. 


\section{The Jesner Decision}

Against this background, expectations in the wake of the Supreme Court's decision in Jesner were high. ${ }^{109}$ The petitioners in Jesner, the majority of which were foreign nationals, ${ }^{110}$ alleged that the defendant, Arab Bank, had facilitated "terrorist attacks committed in Israel, the West Bank, and Gaza between 1995 and 2005 by maintaining accounts for known terrorists, accepting donations that would be used to fund terrorism, and distributing millions of dollars to families of suicide bombers (so-called 'martyrdom payments')."'11 Arab Bank is a major Jordanian financial institution with over 600 branches worldwide. ${ }^{112}$ In the lawsuit, it described itself as "an active and leading partner in the socio-economic development" of the Middle East. ${ }^{113}$ The decision notes that the Israeli government has worked with the bank to transfer taxes collected for the Palestinian Authority, and the United States government characterized the bank as a "constructive partner" in its efforts to combat money laundering and the financing of terrorism. ${ }^{114}$ In their complaint, the petitioners alleged that Arab Bank used its New York branch to clear dollar-denominated transactions that benefitted terrorists through the Clearing House Interbank Payment System (CHIPS). ${ }^{115}$ Dollar-denominated transactions are often used by foreign banks to facilitate currency exchanges/transactions between foreign banks, and CHIPS is commonly used for such transactions and for transactions where the dollar is used as an intermediate currency to facilitate currency exchange. ${ }^{116}$ The transactions are mechanical, without human intervention, and nearly instantaneous. ${ }^{117}$ They occur predominantly in the United States

109. See, e.g., Beth Van Schaak, The Inconsequential Choice-of-Law Question Posed by Jesner v. Arab Bank, 24 ILSA J. INT'L \& ComP. L. 359, 368 (2018) (suggesting that the Supreme Court "should continue to leave the door open to corporate liability under the ATS”)(citing Sosa v. Alvarez-Machain, 542 U.S. 692, 729 (2004)).

110. See Jesner v. Arab Bank, PLC, 138 S. Ct. 1386, 1394 (2018) (“A significant majority of the plaintiffs in these lawsuits - about 6,000 of them - are foreign nationals whose claims arise under the ATS. These foreign nationals are petitioners here.").

111. Sterio, supra note 13, at 129 (citing complaint at *38, Jesner v. Arab Bank, PLC, No. CV 06 3869, 2006 WL 4807223 (E.D.N.Y. Aug. 9, 2006)).

112. See Jesner, 138 S. Ct. at 1394; see also Amy Howe, An Introduction to the Alien Tort Statute and Corporate Liability: In Plain English, SCOTUSBLOG (July 24, 2017), http://w ww.scotusblog.com/2017/07/introduction-alien-tort-statute-corporate-liability-plain-english/ [https://perma.cc/95QL-XLDJ] (describing the ATS and summarizing ATS case law).

113. Jesner, 138 S. Ct. at 1394.

114. Id.

115. Id.

116. Id.

117. Id. at 1395. 
but are also used by major foreign banks both in the United States and abroad. ${ }^{118}$ Additionally, the petitioners claimed that Arab Bank used its New York branch to launder money for a Texas-based charity "affiliated with Hamas." $" 119$

Against these factual circumstances, the Supreme Court, in Jesner, finally addressed the question whether the United States judiciary has authority in an ATS action to determine if a corporation has, by its human agents, violated tenets of international law that protect human rights and impose liability on the corporation. ${ }^{120}$ To answer this question two analyses must occur: (1) Does the law of nations impose liability on corporations for human rights violations committed by its employees; and (2) do courts have the authority and discretion in an ATS suit to impose liability on a corporation without a specific direction from Congress to do so? $?^{121}$

Regarding the first question, the Supreme Court discussed whether there was a specific, universal, and obligatory norm of corporate liability under international law. ${ }^{122}$ Justice Kennedy, delivering the opinion for the majority, argued that jurisdiction of historical international criminal tribunals, such as the Nuremberg Military Tribunals, as well as more recent international tribunals was limited to natural persons, supporting the position that there was no such norm. ${ }^{123}$ The Court ultimately did not make a final decision on the issue. Instead, it stated, "[t]here is at least sufficient doubt on the point to turn to Sosa's second question - whether the Judiciary must defer to Congress, allowing it to determine in the first instance whether that universal norm has been recognized and, if so, whether it is prudent and necessary to direct its enforcement in suits under the ATS."

In answering that question, the Court looked for a "statutory analogy to an ATS common-law action" in the Torture Victim Protection Act of 1991 (TVPA), which created an express cause of action for victims of torture and

118. Id. at 1394-95.

119. Id. at 1395.

120. Id. at 1394.

121. Id.

122. Id. at 1400 ("In the Court of Appeals' decision in Kiobel, the majority opinion by Judge Cabranes interpreted footnote 20 to mean that corporate defendants may be held liable under the ATS only if there is a specific, universal, and obligatory norm that corporations are liable for violations of international law.") (citing Kiobel v. Royal Dutch Petroleum Co., 621 F.3d 111, 127 (2d Cir. 2010)).

123. See Jesner, $138 \mathrm{~S}$. Ct. at 1401 (noting " $[\mathrm{t}] \mathrm{he}$ drafters of the Rome Statute considered, but rejected, a proposal to give the International Criminal Court jurisdiction over corporations.") (citing Albin Eser, Individual Criminal Responsibility, in 1 THE Rome

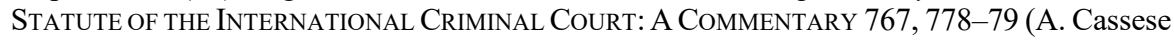
et al. eds. 2002)).

124. Id. at 1402 . 
extrajudicial killing in violation of international law. ${ }^{125}$ It argued, "[t]he key feature of the TVPA for this case is that it limits liability to 'individuals,' which, the Court has held, unambiguously limits liability to natural persons. ${ }^{126}$ When enacting the TVPA, Congress carefully delineated the law's boundaries so that it could "weigh the foreign-policy implications of its rule." "27 "The TVPA reflects Congress' considered judgment of the proper structure for a right of action under the ATS." ${ }^{\prime 28}$ From this, the Court concluded, "[a]bsent a compelling justification, courts should not deviate from that model." $" 129$

On the second question, the Court analyzed the ATS. It found that when enacted, the statute was intended to only "furnish jurisdiction for a relatively modest set of actions alleging violations of the law of nations." 130 The Court reaffirmed its holding in Sosa that "[t]he ATS is 'strictly jurisdictional' and does not by its own terms provide or delineate the definition of a cause of action for violations of international law." ${ }^{131}$ Its main objective at the time of its creation was to "avoid foreign entanglements by ensuring the availability of a federal forum where the failure to provide one might cause another nation to hold the United States responsible for an injury to a foreign citizen." 132 In Jesner, according to the majority, quite the opposite was true, as the long-drawn litigation apparently had put a strain on United StatesJordanian relations. The Court did not answer the question of whether proper application of Sosa would preclude courts from ever recognizing new ATS causes of action. According to the majority, separation-of-powers concerns prevent courts from extending ATS liability to foreign corporations absent further action from Congress. ${ }^{133}$ Additionally, the Court was concerned that extending liability under the ATS to corporations "would imply that other nations, also applying the law of nations, could hale [U.S. corporations] into their courts for alleged violations of the law of nations." 134 This increased global risk, in turn, could "hinder global investment in developing economies, where it is most needed." $" 135$

125. Id. at 1403.

126. Id. at 1404 (citing Mohamad v. Palestinian Auth., 566 U.S. 449, $453-56$ (2012)).

127. Id. at 1403 (citing Kiobel v. Royal Dutch Petroleum Co., 569 U.S. 108, 117 (2013)).

128. Id.

129. Id.

130. Id. at 1397 (quoting Sosa v. Alvarez-Machain, 542 U.S. 692, 720 (2004)) (internal quotations omitted).

131. Id. at 1389 (citing Sosa, 542 U.S. at 713-14).

132. Id. at 1397 (citing Sosa, 542 U.S. at 715-19; Kiobel, 569 U.S. at 123-24).

133. Id. at $1402-03$.

134. Id. at 1405 (quoting Kiobel, 569 U.S. at 124).

135. Id. at 1405-06 (quoting Brief for United States as Amicus Curiae in American Isuzu 
Based on these considerations, the Court decided that common-law liability under the ATS did not extend to corporations and thus, foreign corporate defendants could not be sued before a federal U.S. court based on the ATS. This finding leads to the following question. If the ATS is of jurisdictional nature, and, as the Supreme Court suggests, does not allow foreign plaintiffs to sue a foreign corporation before a U.S. federal court, which courts do have jurisdiction over corporate human rights abuses committed by MNCs worldwide and which are the rules that determine the applicable law to private causes of action in these cases? This, in the absence of international norms and tribunals, is a question for domestic courts or legislators to decide and potentially leads to protection gaps for plaintiffvictims if the jurisdictional or conflict of law norms diverge between jurisdictions. The following Part will address these issues under current U.S. law, and, as an example for a foreign jurisdiction, the law of the EU and, where appropriate, selected individual EU member states. The analysis will show areas of convergence as well as remaining differences and discuss how these tendencies might inform a future harmonized legal regime for international civil corporate human rights litigation.

\section{THE ATS AND JURISDICTION OVER FOREIGN DEFENDANTS IN U.S. COURTS}

While previous sections have addressed the subject-matter and international law questions raised in previous ATS decisions, this section looks at the ATS's role in determining U.S. court's jurisdiction over foreign corporate defendants and its relationship to the Supreme Court's personal jurisdiction rules for this matter. Personal jurisdiction, surprisingly, despite the factual similarities between both cases, was not at issue in the Jesner litigation, but was at the center of the Supreme Court's decision in Daimler. Daimler and related recent personal jurisdiction decisions, however, leave important questions unanswered. The courts could have addressed these issues in the Jesner litigation, but — surprisingly — the defendant did not claim a lack of personal jurisdiction. ${ }^{136}$ Hence, personal jurisdiction will continue to be a source of controversy in private human rights cases and beyond, even with the door arguably closing on the ATS.

The following sections first analyze the ATS's role in determining

Motors, Inc. v. Ntsebeza, O.T. 2007, No. 07-919, p. 20) (internal quotations omitted).

136. See generally Linda J. Silberman, The End of Another Era: Reflections on Daimler and its Implications for Judicial Jurisdiction in the United States, 19 LeWIS \& CLARK L. REV. 675 (2015) (discussing several unanswered questions that remained after Daimler). 
jurisdiction over foreign corporate defendants. They then analyze how, hypothetically, Daimler and related decisions could have affected Jesner, or are likely to affect future litigation outside the ATS. The section after that looks at related procedural rules in Europe and draws conclusions for desirable changes to U.S. law and implications for a harmonized international system.

\section{A. The ATS as Jurisdictional Statute}

The Supreme Court, in Sosa, held that the ATS was a jurisdictional statute. ${ }^{137}$ According to the majority in Jesner - as mentioned above - " $[t]$ he principal objective of the statute, when first enacted, was to avoid foreign entanglements by ensuring the availability of a federal forum where the failure to provide one might cause another nation to hold the United States responsible for an injury to a foreign citizen." ${ }^{138}$ In these cases, the ATS creates original jurisdiction for the federal courts to hear "any civil action by an alien for a tort only, committed in violation of the law of nations or a treaty of the United States." ${ }^{139}$ Hence, as a jurisdictional statute, the ATS addresses subject matter jurisdiction but says nothing about jurisdiction over the particular defendant. This is a question of personal jurisdiction. Personal jurisdiction is the requirement that a given court have power over the defendant. It typically raises the question of a sufficient connection between the dispute and the forum to justify requiring the defendant to stand trial before - for this purpose - any U.S. federal or state court. ${ }^{140}$ Subject-matter jurisdiction, on the other hand, is the authority of the court to hear a specific type of claim. ${ }^{141}$ In ATS cases, due to their international nature, typically both subject-matter jurisdiction and personal jurisdiction are at issue.

137. Sosa, 542 U.S. at 712 .

138. Jesner, 138 S. Ct. at 1397 (citing Sosa, 542 U.S. at 715-19; Kiobel, 569 U.S. at $123-$ 24).

139. It is not clear whether the ATS also applies in disputes between an alien plaintiff and a domestic defendant. See id. at 1426 (Sotomayor, J., dissenting) (stating that "whereas the ATS expressly limits the class of permissible plaintiffs to 'alien[s],' $\S 1350$, it 'does not distinguish among classes of defendants"') (citing Argentine Republic v. Amerada Hess Shipping Corp., 488 U.S. 428 (1989)).

140. See Int'l Shoe Co. v. State of Wash., 326 U.S. 310, 320 (1945) (requiring "sufficient contacts or ties with the state of the forum to make it reasonable and just according to our traditional conception of fair play and substantial justice to permit the state to enforce the obligations which appellant has incurred there.").

141. See Lightfoot v. Cendant Mortg. Corp., 137 S. Ct. 553, 560 (2017) (stating that "a court's subject-matter jurisdiction defines its power to hear cases") (citing Steel Co. v. Citizens for Better Env't, 523 U.S. 83, 89 (1998)); Wachovia Bank, N.A. v. Schmidt, 546 U.S. 303, 316 (2006)) (internal citations omitted). 
Subject-matter jurisdiction, generally, is given if the case presents a federal question ${ }^{142}$ or in the case of diversity, i.e. if the case involves:

(1) citizens of different States;

(2) citizens of a State and citizens or subjects of a foreign state, except that the district courts shall not have original jurisdiction under this subsection of an action between citizens of a State and citizens or subjects of a foreign state who are lawfully admitted for permanent residence in the United States and are domiciled in the same State;

(3) citizens of different States and in which citizens or subjects of a foreign state are additional parties; and

(4) a foreign state, defined in section 1603(a) of this title, as plaintiff and citizens of a State or of different States. ${ }^{143}$

In private human rights related cases between a foreign citizen and a foreign corporation, diversity jurisdiction per the criteria enumerated above would typically be missing because - as the district court in Jesner arguedboth parties were aliens. ${ }^{144}$ Federal question jurisdiction requires that the claim arises out of federal law or is of significant federal interest. ${ }^{145}$ Federal law includes treaties of the Unites States. ${ }^{146}$ Hence, one could argue that international human rights norms that are part of a U.S.-ratified international treaty are actionable before federal courts, even without having to rely on the ATS. $^{147}$ However, the U.S. government has declared most human rights treaties to be non-self-executing, meaning that they would require implementing legislation to be actionable. ${ }^{148}$ Whether international norms

142. See 28 U.S.C. $\S 1331$ (laying out the rules for subject-matter jurisdiction).

143. 28 U.S.C. $\S 1332$.

144. See In re Arab Bank, PLC Alien Tort Stat. Litig., 808 F.3d 144, 160 (2d Cir. 2015) ("Following the dismissal of the plaintiffs' ATS claims, the only basis on which the district court might exercise jurisdiction over these actions would be diversity of citizenship. But 'diversity is lacking ... where the only parties are foreign entities, or where on one side there are citizens and aliens and on the opposite side there are only aliens."') (citing Universal Licensing Corp. v. Paola del Lungo S.p.A., 293 F.3d 579, 581 (2d Cir.2002)). Diversity jurisdiction, however, does allow for civil actions brought by an alien against a domestic U.S. corporation according to para. 2 of the ATS, and suits between a U.S. citizen and a U.S. corporation, in which citizens or subjects of a foreign state are additional parties. 28 U.S.C. $\S 1332$.

145. See Grable \& Sons Metal Products, Inc. v. Darue Eng'g \& Mfg., 545 U.S. 308, 312 (2005) (citing Hopkins v. Walker, 244 U.S. 486, 490-91 (1917).

146. 28 U.S.C. $\S 1331$.

147. See Jesner v. Arab Bank, PLC, 138 S. Ct. 1386, 1424 (2018) (Sotomayor, J., dissenting) (providing multiple examples for international conventions, which specifically impose liability on corporations for certain norms of international law, such as financing terrorism or bribery).

148. See Anna Triponel, Business \& Human Rights Law: Diverging Trends in the United 
beyond those treaties, i.e. customary international law, provide for federal subject-matter jurisdiction as part of federal common law, is even less certain. The question was at issue in Sosa. ${ }^{149}$ Here, Justice Scalia argued that following the Court's decision in Erie Railroad Co. v. Tompkins, federal courts must refrain from creating common law. ${ }^{150}$ Hence, he argued, "[t]he question is not what case or congressional action prevents federal courts from applying the law of nations as part of the general common law; it is what authorizes that peculiar exception from Erie's fundamental holding that a general common law does not exist." ${ }^{\prime 15}$ The insight lead Scalia to conclude that the courts were precluded from granting jurisdiction under the ATS for cases based on international norms other than those that Congress had in mind when enacting the statute-namely "interference with ambassadors, and piracy." 152 The majority in Sosa, however, recognized "limited enclaves in which federal courts may derive from substantive law in a common law way,' including the law of nations."153 The question was not at issue in Jesner. Nevertheless, diverging arguments expressed by Justice Gorsuch and Justice Sotomayor in their concurrence and dissenting opinion, respectively, suggest that Sosa was not the Court's last word in this matter. ${ }^{154}$ While Justice Gorsuch, in line with Justice Scalia's opinion in Sosa, suggested limiting courts' discretion to recognize new causes of action under the ATS, ${ }^{155}$ Justice Sotomayor argued that Congress "granted the federal courts jurisdiction over claims based on 'the law of nations,' a body of law that Congress did not understand to be static. ${ }^{156}$ The dispute ought not to be decided here. Even if one follows Justice Sotomayor's broad interpretation,

States and France, 23 AM. U. INT'L L. REV. 855, 863 (2008) (citing Kenneth Roth, The Charade of US Ratification of International Human Rights Treaties, 1 CHI. J. INT'L L. 347, 348-49 (2000)).

149. Sosa v. Alvarez-Machain, 542 U.S. 692, 729-30 (2004) (explaining that, following Erie, there are "limited enclaves in which federal courts may derive from substantive law in a common law way," including the law of nations).

150. See generally Erie R. Co. v. Tompkins, 304 U.S. 64 (1938).

151. Sosa, 542 U.S. 692, 744 (2004) (Scalia, J., concurring).

152. Jesner, 138 S. Ct. at 1392 (Gorsuch, J., concurring) (citing Sosa, 542 U.S. at 715).

153. Id. at 1428 (Sotomayor, J., dissenting) (citing Sosa, 542 U.S. at 729-30).

154. See Sosa, 542 U.S. at 732 ("[F]ederal courts should not recognize private claims under federal common law for violations of any international law norm with less definite content and acceptance among civilized nations than the historical paradigms familiar when $\S 1350$ was enacted.").

155. See Jesner, 138 S. Ct. at 1419 (Gorsuch, J., concurring) (stating that "the decision to impose sanctions in disputes between foreigners over international norms is not ours to make").

156. Id. at 1427 (Sotomayor, J., dissenting) (citing United States v. La Jeune Eugenie, 26 F.Cas. 832, 846 (C.C.D. Mass. 1822)). 
the ATS only provides subject-matter jurisdiction. Hence, plaintiffs' ability to sue a foreign corporation before U.S. courts would still depend upon the court's personal jurisdiction over the defendant, which largely depends on sufficient connections between the defendant and the forum.

However, the Supreme Court in Kiobel discussed the issue of sufficient connections to the United States-typically an issue of personal jurisdiction - as part of ATS jurisdiction. It found that a suit under the ATS could not be brought without some connection to the United States based on the presumption against extraterritoriality. ${ }^{157}$ In doing so, the Court unnecessarily restricted federal ATS jurisdiction and blurred the lines between subject-matter and personal jurisdiction. It would have been analytically clearer, and potentially lead to more coherent results, to discuss sufficient connections between the dispute and the forum as part of the personal jurisdiction analysis. The odd result of the Supreme Court's limitations on ATS jurisdiction in Kiobel, and further restrictions in Jesner, is that these decisions remove human rights litigation and similar issues involving international norms against foreign defendants from the jurisdiction of federal courts. ${ }^{158}$ This will lead more and more plaintiffs to sue foreign corporations before state courts based on far-reaching jurisdictional state statutes. This is a more than questionable result, given the international character of these cases. Moreover, even with a broader interpretation of the ATS, nothing would prevent a federal court from declining to decide a case that lacks a sufficient connection to the U.S. territory as a matter of a personal jurisdiction.

Despite the Supreme Court's unequivocal acknowledgement of the ATS's jurisdictional role, the Court continues to blur the lines, not only between subject-matter jurisdiction and personal jurisdiction, but also between procedural and substantive law. In Jesner, the Court explicitly avoided deciding the question of sufficient connections between the dispute and the territory of the United States. Instead, it argued that " $[\mathrm{t}]$ he question whether foreign corporations are subject to liability under the ATS should be addressed; for, if there is no liability for Arab Bank, the lengthy and costly

157. See Kiobel v. Royal Dutch Petroleum Co., 569 U.S. 108, 117 (2013) ("The principles underlying the presumption against extraterritoriality thus constrain courts exercising their power under the ATS."').

158. See also Jesner, $138 \mathrm{~S}$. Ct. at 1434 (Sotomayor, J., dissenting) (stating that "the First Congress created the ATS because it wanted foreign plaintiffs to be able to bring their claims in federal court and sue for law-of-nations violations. A suit for state law battery, even if based on the same alleged conduct, is not the equivalent of a federal suit for torture; the latter contributes to the uptake of international human rights norms, and the former does not.") (internal citations omitted). 
litigation concerning whether corporate contacts like those alleged here suffice to impose liability would be pointless." ${ }^{.159}$ As laudable as the Court's concern for the economic costs and diplomatic tensions resulting from prolonged litigation are, the argument camouflages the true issue at stake in private international human rights litigation, which is the question of whether U.S. courts should hear disputes arising out of human rights violations between two private, foreign parties. ${ }^{160}$ Admitting "foreign-cubed" cases before U.S. courts raises questions of litigation fairness for plaintiffs and defendants, concerns the power relationship between the forum and the defendant, and raises sovereignty issues between the United States and foreign states. Courts traditionally have discussed these issues as part of personal jurisdiction. ${ }^{161}$ Some foreign courts, as will be discussed later, view them-maybe even more fittingly — as an issue of a domestic court's "international competence" to decide an international case. ${ }^{162}$ The question, whether foreign corporations may be held liable for human rights abuses under international law, which was at the center of discussion in Jesner, however, is a substantive issue. It raises two questions: first, if a corporation as a legal entity, as opposed to its human agents, can be liable for its complicity in human rights abuses, and, second, how such a claim may be enforced. ${ }^{163}$ For the purpose of subject-matter jurisdiction under the ATS, however, an allegation of a "violation of the law of nations or a treaty of the United States" is sufficient. ${ }^{164}$ Hence, courts should only address this question once jurisdiction over the case has been established, even if doing

159. See Jesner, 138 S. Ct. at 1399 (stating that " $[\mathrm{t}]$ he question whether foreign corporations are subject to liability under the ATS should be addressed; for, if there is no liability for Arab Bank, the lengthy and costly litigation concerning whether corporate contacts like those alleged here suffice to impose liability would be pointless").

160. See id. at 1398 ("Modern ATS litigation has the potential to involve large groups of foreign plaintiffs suing foreign corporations in the United States for alleged human rights violations in other nations.... The extent and scope of this litigation in United States courts have resulted in criticism here and abroad.") (internal citations omitted).

161. See Morrison v. Nat'l Austl. Bank Ltd., 561 U.S. 247, 283 n.11 (2010) (defining foreign-cubed cases as "actions in which '(1) foreign plaintiffs [are] suing (2) a foreign [defendant] in an American court for violations of American ... laws based on ... . transactions in (3) foreign countries"' (quoting Morrison v. Nat'l Austl. Bank Ltd., 547 F.3d 167, 172 (2d Cir. 2008))).

162. See infra notes $208-214 \&$ accompanying text.

163. See Jesner, 138 S. Ct. at 1420 (Sotomayor, J., dissenting) (distinguishing between "international norms" and "enforcement mechanisms" and arguing that per the Court's decision in Sosa, human rights qualify as international norms under the ATS while there is no need for international consensus on how these norms are being enforced. Corporate liability, Justice Sotomayor argues, is part of the enforcement mechanism, not the underlying international norm, which "could be violated").

164. 28 U.S.C. $\S 1450$. 
so leads to prolonged litigation, which, in fact, is due to shortcomings in current personal jurisdiction rules, rather than the examination of a foreign corporation's ties to the United States in a given case. ${ }^{165}$

\section{B. Personal Jurisdiction over Foreign Corporate Defendants in International Human Rights Cases}

The Supreme Court addressed personal jurisdiction over foreign corporate defendants in its decision in Daimler, as well as other - not human rights related-recent decisions involving foreign corporate defendants before U.S. courts, such as J. McIntyre Machinery, Ltd. v. Nicastro and Goodyear Dunlop Tire Operations, S.A. v. Brown. ${ }^{166}$ Against the background of years of mostly broad but inconsistent practice in the lower courts, the Supreme Court's recent decisions significantly restrict personal jurisdiction over out-of-state corporations-and foreign corporations, specifically. ${ }^{167}$ However, despite the court having decided five personal jurisdiction cases between 2011 and 2017 alone, important questions remain unanswered and could affect plaintiffs' ability to sue corporations for their complicity in human rights violations before U.S. federal or state courts. The following part examines how the Court's latest restriction on both general and specific personal jurisdiction would have affected the Jesner litigation if personal jurisdiction had been raised. It then discusses how unresolved jurisdictional questions may affect international human rights litigation against corporate defendants and shows avenues for a more balanced and harmonized approach.

165. See Daimler AG v. Bauman, 571 U.S. 117, 154-56 (2014) (Sotomayor, J., concurring) (criticizing the majority's comparative contacts test).

166. See generally J. McIntyre Mach., Ltd. v. Nicastro, 564 U.S. 873 (2011) (holding that a state can exercise jurisdiction over a foreign manufacturer because said manufacturer did not engage in conduct purposefully directed at the state); Goodyear Dunlop Tires Operations, S.A. v. Brown, 564 U.S. 915 (2011); see also Bristol-Myers Squibb Co. v. Superior Court, 137 S. Ct. 1773 (2017) and Walden v. Fiore, 571 U.S. 277 (2014) (demonstrating the trend towards restricted personal jurisdiction, though these cases do not involve foreign corporate defendants, but a domestic out-of-state corporation and an out-of-state individual respectively).

167. See Berger-Walliser, supra note 20 at 1248 ("In a series of cases decided between 2011 and 2017, the Supreme Court appeared to take steps toward gradually restricting personal jurisdiction over corporate defendants in general-and foreign corporations specifically."); see also Patrick J. Borchers, The Twilight of the Minimum Contacts Test, 11 Seton Hall Cir. Rev. 1, 4 (2014) (summarizing the 2011-2014 decisions). 


\section{1. "At Home" General Jurisdiction}

In Daimler, the Court addressed the question as to "whether the Due Process Clause of the Fourteenth Amendment preclude[d a California c]ourt from exercising jurisdiction over [the German public corporation] Daimler . . . given the absence of any California connection" to the charges alleged in the complaint. ${ }^{168}$ In Daimler, plaintiffs sought to hold Daimler vicariously liable for its Argentinian subsidiary of Mercedes-Benz for the latter's actions during the Argentine "Dirty War" period. ${ }^{169}$ Neither the subsidiary's actions took place in California, nor were the plaintiffs from California. ${ }^{170}$ Instead, plaintiffs attempted to establish jurisdiction based on the contacts of Daimler's indirect subsidiary, Mercedes-Benz USA (MBUSA), in California. ${ }^{171}$ Hence, like Jesner, the case involved foreign plaintiffs suing a foreign corporation before a U.S. federal court based on that corporation's subsidiary's complicity in human rights violations suffered by non-resident victims in a foreign country. Contrary to Jesner, the subsidiary involved with the alleged human rights abuses itself was not situated in the forum state and none of the actions giving raise to the suit took place in the forum. ${ }^{172}$

The Supreme Court in Daimler concluded that under a state's long-arm statute, a state court is allowed the exercise of personal jurisdiction over a party to the fullest extent possible so long as it is permissible under the United States Constitution. ${ }^{173}$ Applying its precedent developed three years earlier in Goodyear, the Supreme Court held that to exercise general jurisdiction, as the plaintiffs in Daimler attempted to establish, not only would the out-of-state defendant need to engage in continuous and systematic activities in the forum state, but those activities would need to be so substantial and of such nature as "to render them essentially at home in the forum State." 174 It noted, for a corporation to be considered "at home" in a jurisdiction, except for "exceptional case[s]," "t75 "the place of incorporation

168. Daimler, 571 U.S. at 121.

169. Id.

170. Id.

171. The potential for a foreign corporation to be held under a state court's jurisdiction due to the contacts of its subsidiary will be discussed in Part II(B)(2).

172. In Jesner, the U.S. subsidiary itself was complicit in human rights violations, while in Daimler, only the Argentinean subsidiary was. The consequences of these factual differences will be addressed later in Part II(B)(2). See infra, text accompanying note 184.

173. See Daimler, 571 U.S. at 125 (explaining that federal courts ordinarily follow state law in determining the bounds of their jurisdiction over individuals).

174. Id. at 122 (citing Goodyear Dunlop Tires Operations, S.A. v. Brown, 564 U.S. 915 , 919 (2011).

175. Id. at 139 n. 19 . 
and the principal place of business are 'paradig[m] ... bases for general jurisdiction." ${ }^{176}$ Since Daimler AG was neither incorporated nor did it have its principal place of business in California, the Court concluded that California courts lacked personal jurisdiction. Daimler was "an easy case" as even the dissenting minority acknowledged that Daimler's connection to California was too weak to establish jurisdiction over the German parent. ${ }^{177}$ The Court did not provide much guidance on circumstances under which a corporation might be at home in a jurisdiction outside the "paradigm forums," but "[did] not foreclose the possibility that in an exceptional case ... a corporation's operations in a forum other than its formal place of incorporation or principal place of business may be so substantial and of such a nature as to render the corporation at home in that State."178

In light of Jesner, the question arises whether a corporation's in-state subsidiary may suffice to render a foreign corporation "at home" in that state. The Supreme Court, in Daimler, rejected the Ninth Circuit's agency approach to establishing general jurisdiction, calling it far too broad, as it would "subject foreign corporations to general jurisdiction whenever they have an in-state subsidiary or affiliate, an outcome that would sweep beyond even the 'sprawling view of general jurisdiction'... rejected in Goodyear." "179 Jurisdiction over a foreign, parent corporation based on human rights abuses committed by its in-state subsidiary are thereby primarily a question of specific jurisdiction.

176. Id. at 137 (quoting Brilmayer et al., A General Look at General Jurisdiction, 66 TEX. L. REV. 721,735 (1988)).

177. See id. at 142 (Sotomayor, J., concurring) (pointing to the "unique circumstances of this case").

178. Id. at 139 n.19. Compare Perkins v. Benguet Consol. Mining Co., 342 U.S. 437, 448 (1952) (holding that an Ohio court could establish general jurisdiction over a foreign corporation because the State "was the corporation's principal, if temporary, place of business"), with Helicopteros Nacionales de Colom., S.A. v. Hall, 466 U.S. 408, 416-18 (1984) (describing a Colombian company's contacts with the forum State, which were limited to "sending its chief executive officer to Houston for a contract-negotiation session; accepting into its New York bank account checks drawn on a Houston bank; purchasing helicopters, equipment, and training services from [a Texas-based helicopter company] for substantial sums; and sending personnel to [Texas] for training," before stating that "mere purchases, even if occurring at regular intervals, are not enough to warrant a State's assertion of in personam jurisdiction over a non-resident corporation in a cause of action not related to those purchase transactions").

179. Daimler, 571 U.S. at 136 (quoting Goodyear, 564 U.S. at 929). 


\section{Agency Relationship Based Specific Jurisdiction}

Since International Shoe Co. v. State of Washington, ${ }^{180}$ for a court to exercise specific jurisdiction over an out-of-state defendant, the defendant must be engaged in "continuous and systematic" in-state activities that "also give rise to the liabilities sued on."181 Those activities can be performed not only by the corporate defendant itself, ${ }^{182}$ but also by its authorized agent, as long as they are of such nature as to justify subjecting the corporation to suit in that state. ${ }^{183}$ Unlike in Daimler, the facts in Jesner raise the question of specific jurisdiction based on such agency relationship, since contrary to Daimler, Arab Bank's New York branch performed activities in the forum state, which were - at least somehow-connected to the suit. ${ }^{184}$ The activities of Arab Bank's New York branch satisfying the due process criteria set forth in Int'l Shoe and its progeny is a factual question not conclusively answered in Jesner.

Looking at relevant Supreme Court precedent, the criteria under which the activities of a third party can be attributed to the principal are not entirely clear. The Court in Int'l Shoe recognized that when commercial activities are "carried on in behalf of" an out-of-state party, those activities may sometimes be ascribed to the party. ${ }^{185}$ In Burger King it noted, "at least where he [the out-of-state party] is a 'primary participan[t]' in the enterprise and has acted purposefully in directing those activities." 186 Recently, in Bristol-Myers Squibb Co. v. Superior Court, the Court stated that " "[t]he

180. Int'l Shoe Co. v. State of Wash., 326 U.S. 310 (1945).

181. See Int'l Shoe, 326 U.S. at 317; Cf. Helicopteros Nacionales, 466 U.S. at 414 n.8 (noting that adjudicatory authority where the suit "aris[es] out of or relate[s] to the defendant's contacts with the forum" is specific jurisdiction).

182. See Int'l Shoe, 326 U.S. at 318 (stating that "although the commission of some single or occasional acts of the corporate agent in a state sufficient to impose an obligation or liability on the corporation has not been thought to confer upon the state authority to enforce it... other such acts, because of their nature and quality and the circumstances of their commission, may be deemed sufficient to render the corporation liable to suit") (internal citations omitted).

183. See id. at 319 ("[T] activities which justify the subjection of a corporation to suit, and those which do not, cannot be simply mechanical or quantitative. The test is not merely, as has sometimes been suggested, whether the activity, which the corporation has seen fit to procure through its agents in another state, is a little more or a little less.") (internal citations omitted).

184. See Daimler, 571 U.S. at 135 n.13 ("Agency relationships, we have recognized, may be relevant to the existence of specific jurisdiction. ... It does not inevitably follow, however, that similar reasoning applies to general jurisdiction.") (internal citations omitted).

185. Int'l Shoe, 326 U.S. at 310.

186. Burger King Corp. v. Rudzewicz, 471 U.S. 462, 479 n.22 (1985) (citing Calder v. Jones, 465 U.S. 790 (1984)). 
requirements of International Shoe ... must be met as to each defendant over whom a state court exercises jurisdiction." 187 "[A] defendant's relationship with a ... third party, standing alone, is an insufficient basis for jurisdiction." ${ }^{188}$ Against this background, it seems unlikely that the Court will allow the actions of a third party, including subsidiaries not completely dominated by their out-of-state parent corporation, to transpose to the defendant who has not purposefully availed itself to that forum. ${ }^{189}$ The latter, in Jesner, seems questionable due to the automated and generic nature of the Clearing House Interbank Payments System (CHIPS) allegedly used for Arab Bank's financial transactions through its New York branch. ${ }^{190}$ Given the fact that CHIPS does not require human intervention and is used by other major banks in the United States and internationally, Arab bank could have relied on the services of any bank using CHIPS as an intermediary for its dollar-denominated transactions. ${ }^{191}$ In this regard, Arab Bank neither dominates its New York subsidiary nor are the subsidiaries' transactions indicative of "continuous and systematic" in-state activities. It is also uncertain that Arab Bank played a dominant, if any, role in the branches' alleged money laundering activities for the Texas-based charity affiliated with Hamas.

Even if the branches' actions could be attributed to the parent to establish specific personal jurisdiction in this or similar cases, the question still remains whether it were these activities that gave rise to the suit. This raises the question, where, in human-rights related corporate liability cases, the relevant actions took place. Two options are to be considered: (1) the place where the corporate activity occurred, which-in case of a U.S. corporation or a U.S. subsidiary of a foreign corporation - could establish jurisdiction before U.S. courts; or (2) the place where the plaintiff(s) suffered the alleged human rights violations. The Supreme Court, thus far, did not get a chance to decide on the issue. However, its recent focus on state sovereignty rights and sufficient connections between the case and the forum

187. Bristol-Myers Squibb Co. v. Superior Court, 137 S. Ct. 1773, 1783 (2017) (citing Rush v. Savchuk, 444 U.S. 320, 332 (1980)).

188. Walden v. Fiore, 571 U.S. 277, 286 (2014); see also Rush, 444 U.S. at 332 (stating that "if a defendant has certain judicially cognizable ties with a State, a variety of factors relating to the particular cause of action may be relevant to the determination whether the exercise of jurisdiction would comport with 'traditional notions of fair play and substantial justice"”).

189. See Berger-Walliser, supra note 20, at 1275 (speculating on the Court's attitude towards assigning contacts from a subsidiary to a parent for jurisdictional purposes).

190. See Jesner v. Arab Bank, PLC, 138 S. Ct. 1386, 1395 (2018) (describing CHIPS).

191. Id. 
suggests that the Court would rather opt for the second option. ${ }^{192}$ As the place where the plaintiffs suffered the alleged human rights violations is often outside of the United States, the latter would typically deny foreign plaintiffs' access to U.S. courts due to a lack of specific jurisdiction.

The Supreme Court's emphasis on defendants' rights is the result of farreaching long arm statutes and the constitutionalization of personal jurisdiction in the post Int'l Shoe era. ${ }^{193}$ If limitations on personal jurisdiction are predominantly conceived as an issue of a defendant's due process rights, it easily follows that defendant protection prevails over plaintiffs' need for effective access to a forum. ${ }^{194}$ But this is not a fatality. The Court's one-sided focus has been criticized, for example, by the minority in the Supreme Court's highly controversial McIntyre decision-an international products liability case. Here, the minority proposed a more nuanced and balanced approach to personal jurisdiction based on reasonableness and fairness. ${ }^{195}$ It should be noted that precedent supports taking into account the forum state's and other parties' interests in a particular forum, as exemplified by Int'l Shoe's reliance on "traditional notions of fair play and substantial justice." ${ }^{, 196}$ In $M c G e e$, the Court expressly invoked "highly realistic" factors such as an insurance policy holder's effective lack of redress if not allowed to sue the insurer at home. ${ }^{197}$ In Burger King Corp. v. Rudzewicz, the Court stated that "courts in

192. Walden v. Fiore, 571 U.S. 277 (2014); J. McIntyre Mach., Ltd. v. Nicastro, 564 U.S. 873 (2011); see also Borchers, supra note 19, at 30 ("Recently, however, the Court has evaluated contacts as if they are important for their own sake, while denying the relevance of other considerations.").

193. See Berger-Walliser, supra note 20 (analyzing Daimler and pointing towards the remaining differences between US and European rules); see also Borchers, supra note 19, at 34 (stating "[b]y dramatically pulling back the boundaries of constitutional regulation of jurisdiction, states would be forced to draft meaningful long arm statutes").

194. See Borchers, supra note 19, at 29-30 (Brennan, J., dissenting) (citing World-Wide Volkswagen Corp. v. Woodson, 444 U.S. 286, 300 (1980)) (arguing "that the exclusive focus on defendant contacts, without any exploration of any actual inconvenience to the defendant and the need of plaintiff to have access to a forum, undercut the International Shoe rationale of fairness and reasonableness").

195. See McIntyre, 564 U.S. at 903 (Ginsburg, dissenting) (stating " [t]he modern approach to jurisdiction over corporations and other legal entities, ushered in by International Shoe, gave prime place to reason and fairness").

196. See World-Wide Volkswagen Corp. v. Woodson, 444 U.S. 286, 300 (1980) (Brennan, J., dissenting) ("The essential inquiry in locating the constitutional limits on state-court jurisdiction over absent defendants is whether the particular exercise of jurisdiction offends 'traditional notions of fair play and substantial justice."' (quoting Int'l Shoe Co. v. State of Wash., 326 U.S. 310, $316(1945))$ ).

197. See Borchers, supra note 19, at 35 ("In McGee, the Court expressly invoked the consideration that if unable to sue the insurer at home, the policyholder might be left without 
'appropriate case[s]' may evaluate ... 'the plaintiff's interest in obtaining convenient and effective relief,' 'the interstate judicial system's interest in obtaining the most efficient resolution of controversies,' and the 'shared interest of the several States in furthering fundamental substantive social policies." 198 The availability of an effective forum, where plaintiffs will actually be able to pursue their rights, frequently is an issue in international human rights cases. ${ }^{199}$ The lack of judicial protection-typically in the plaintiff's home country, as this is usually where the human rights abuse occurred-may thus justify specific personal jurisdiction over foreign corporations before U.S. courts in cases where corporate actions, which gave rise to the suit, took place in the United States and no effective alternative forum exists. ${ }^{200}$

\section{FOREIGN CORPORATE DEFENDANTS IN INTERNATIONAL HUMAN RIGHTS LITIGATION IN THE EUROPEAN UNION}

The previous part has shown that, with regard to private human rights litigation, U.S. jurisdictional rules to date are fragmented and deficient. Additionally, with its restrictions on ATS jurisdiction, the Supreme Court in Jesner specifically called upon the legislature to develop new rules. ${ }^{201}$ Hence, the statutory jurisdiction regime of the European Union might serve as an example on how to reform the rules governing jurisdiction over foreign corporate defendants in human rights related cases in the United States. Because European rules, as opposed to U.S. case law, were created by the European legislature, they are by their very nature less fragmented. They also represent a compromise between the jurisdictional rules of individual member states and underwent significant revisions prior to 2015, when the current Brussels I bis Regulation, also called Brussels Regulation Recast, entered into force. ${ }^{202}$ The regulation provides common rules on jurisdiction

any practical redress." (citing McGee v. Int'l Life Ins. Co., 355 U.S. 220, 223 (1957))).

198. Burger King Corp. v. Rudzewicz, 471 U.S. 462, 477 (1985) (citing World-Wide Volkswagen Corp., 444 U.S. at 292).

199. See SKINNER, supra note 7 (examining obstacles and barriers that victims of human rights abuse face in obtaining judicial remedies).

200. See also Borchers, supra note 19, at 36 (arguing that "the Court still has room to take into account the plaintiff's need for at least one reasonable forum. The J. McIntyre plurality opinion is not controlling; the two-vote concurrence in the judgment is. Because the concurrence did not adopt the sovereignty dogma of the plurality, it is not binding on lower courts.") (internal citations omitted).

201. See Jesner, 138 S. Ct. at 1403 ("[A]bsent further action from Congress it would be inappropriate for courts to extend ATS liability to foreign corporations.").

202. Council Regulation $1215 / 2012$ of the European Parliament and of the Council of 12 
and enforcement of judgements in international civil and commercial disputes that are binding for courts in all EU member states. ${ }^{203}$ The legislative history of the regulation shows that its drafters were aware of increasing volume of private international human rights litigation and the regulation recast, in part, responds to related jurisdictional problems. ${ }^{204}$ By following at least part of the EU model, U.S. courts or legislators potentially would not only create a more coherent system domestically, but also achieve a more harmonized jurisdictional regime for victims of human rights abuses to bring private claims internationally. ${ }^{205}$ New rules could better balance plaintiffs' and defendants' interests, but they could also respect a state or country's interest in deciding, or have others refrain from deciding, private human rights claims in which the country has a specific interest. ${ }^{206}$ The following sections first give an overview of the European jurisdictional regime before addressing those European norms that apply to private actions by human rights victims against corporate defendants specifically.

\section{A. The European Jurisdictional Regime}

European jurisdictional rules are fundamentally different from U.S. rules in both content and underlying rationale. ${ }^{207}$ It would be beyond the

December 2012 on jurisdiction and the recognition and enforcement of judgments in civil and commercial matters, 2012 O.J. (L 351) 1-32 [hereinafter Council Regulation 1215/2012].

203. See Regulations, Directives and Other Acts, EuROPEAN UniOn (last visited Aug. 25, 2018), https://europa.eu/european-union/eu-law/legal-acts_en [https://perma.cc/2HSV-EET $\mathrm{P}]$ (depicting EU regulations are directly binding without additional domestic legislation, while EU directives require local legislation in each member state).

204. See LuCAS RoORda \& CEDRIC RyngaERT, Business AND Human Rights Litigation in Europe: The Promises Held by Forum of NeCESSITY-BASEd JuRisdiction 5 (last visited Feb. 16, 2019), https://unijuris.sites.uu.nl/wp-content/uploads/sites/9/2014/12/Business-andHuman-Rights-Litigation-in-Europe.-The-Promises-Held-by-Forum-of-Necessity-basedJurisdiction.pdf [https://perma.cc/Z7SE-4EHC] (noting the discussion of a "forum of necessity clause" during the recasting process).

205. Beth Van Schaack, In Defense of Civil Redress: The Domestic Enforcement of Human Rights Norms in the Context of the Proposed Hague Judgments Convention, 42 HARV. INT'L L.J. 141 (2001).

206. See Doe v. Exxon Mobil Corp., 654 F.3d 11, 77 (D.C. Cir. 2011) (pointing, among others, to the example of the government of South Africa, which "complained for six years that an extraterritorial ATS case litigated in the Second Circuit interfered with the operation of its post-apartheid Truth and Reconciliation Commission") (citing Sosa v. AlvarezMachain, 542 U.S. 692, 733 n.21 (2004).

207. See generally Berger-Walliser, supra note 20 (analyzing Daimler and pointing towards the remaining differences between US and European rules); see also Ralf Michaels, Two Paradigms of Jurisdiction, 27 Mich. J. INT'L L. 1003, 1011 (2006) (suggesting "a response to these challenges that builds on the work of both functional comparatists and 
scope of this article to analyze the European jurisdictional regime in detail, but a brief overview is necessary to provide background for those rules that apply specifically in the context of business and human rights, and which will be examined in the next section. ${ }^{208}$

Most European countries have procedural rules that, like their counter parts in the United States, determine subject-matter jurisdiction, personal jurisdiction, and venue. However, in addition to the three jurisdictional issues mentioned before, European domestic courts, when deciding an international case, will first determine if they have "international competence." ${ }^{209}$ International competence is commonly translated into English as jurisdiction. ${ }^{210}$ As such, it is typically compared to personal jurisdiction in the United States. ${ }^{211}$ However, strictly speaking, international competence (or jurisdiction for this matter) has a very different function compared to both personal and subject-matter jurisdiction in the United States. ${ }^{212}$ While personal jurisdiction in the United States is conceptualized as an issue of constitutional due process, rules of international competence in the European Union seek to determine which country's courts are best suited to decide an international case. ${ }^{213}$ This explains why the jurisdiction

students of culture, but provides a way to explain the persistence of differences that overcomes the limits of both: legal paradigms").

208. Scholarship has described the European regime at the occasion of the Brussels Regulation recast and has compared it to U.S. law in the wake of the Supreme Court's recent decisions in McIntyre and Daimler; see, e.g., SAmuel P. Baumgartner, The External Dimensions of the European Law of Civil Procedure - A Transatlantic Perspective, in Der Europäische Gerichtsverbund-Die Internationalen Dimensionen Des EUROPÄISCHEN VERFAHRENSRECHTS 6 (Burkhard Hess, ed., 2017) (attempting "to shed light on the underlying interests with which Europeans on the one hand and Americans on the other are likely to approach treaty negotiations" in transactional litigation); Berger-Walliser, supra note 20; Kate Bonacorsi, Not at Home with "At-Home" Jurisdiction, 37 FordHAm InT'L L.J. 1821 (2014); Patrick J. Borchers, One Step Forward and Two Steps Back: Missed Opportunities in Refining the United States Minimum Contacts Test and the European Union Brussels I Regulation, 31 ARIz. J. INT'L \& COMP. L. 1 (2014).

209. See Berger-Walliser, supra note 20, at 1252 ("International competence deals with the distribution of judicial power between sovereign countries, while the territorial allocation of a case to a court in Berlin or Munich - though these two cities are located in different German federal states (Länder) - is a question of venue (örtliche Zuständigkeit).”).

210. See, e.g., different language versions of Council Regulation 1215/2012, supra note 202 (exhibiting how the regulation's title translates literally from German or French as "Regulation ... on judicial competence," while the official English translation reads "Regulation ... on jurisdiction").

211. Michaels, supra note 207.

212. See Berger-Walliser, supra note 20 , at 1252 (stating "[u]nlike rules of personal jurisdiction in the United States, international competence determines jurisdiction exclusively in the international context").

213. See Berger-Walliser, supra note 20, at 1253 (comparing this function to that typically 
rules provided in the Brussels Regulation take a more balanced approach to the defendant and plaintiff's interest, ${ }^{214}$ but-in the interest of efficiencyequally provide jurisdictional rules which "facilitate the sound administration of justice," sometimes at the detriment of one party. ${ }^{215}$

The Brussels Regulation provides a complete set of codified norms that conclusively regulate personal jurisdiction in the EU member states in private or commercial matters. ${ }^{216}$ This codification explains why, when compared to U.S. personal jurisdiction, the European rules appear to be more predictable than, for example, the "minimum contacts test." 217 It should be noted, however, that some of the regulation's rules are rather complex and have led to extensive commentary and/or case law by the European Court of Justice ("ECJ"). The European rules are thus not necessarily as predictable as a cursory reading of the Brussels Regulation may suggest. ${ }^{218}$ In addition to common jurisdictional rules, the regulation provides that a judgement issued in an EU Member State shall be recognized in another Member State without any special recognition procedure. ${ }^{219}$

The Brussels Regulation applies whenever the defendant is domiciled in a member state of the EU. ${ }^{220}$ This means that it does not only regulate jurisdiction in disputes between parties domiciled within the EU, but also disputes between a non-EU plaintiff and a defendant domiciled in an EU member state. ${ }^{221}$ Disputes between an EU plaintiff and a defendant outside

attributed to choice of law rules); see also Friedrich K. Juenger, Constitutionalizing German Jurisdictional Law, 44 Aм. J. Comp. L. 521, 521 (stating that the United States is unique in constitutionalizing personal jurisdiction).

214. See Berger-Walliser, supra note 20, at 1296 ("The Regulation focuses on the relationship between the court and the claim in order to find the most appropriate forum.").

215. See Council Regulation 1215/2012, supra note 202, at 9 ("[T] alternative grounds of jurisdiction based on a close link between the court and the action or in order to facilitate the sound administration of justice.").

216. See Council Regulation 1215/2012, supra note 202, at art. 1 and 4 (illustrating the scope and jurisdiction of the Council Regulation).

217. See Michaels, supra note 207, at 1008, 1039-52 ("European law... uses hard and fast rules that are easier to apply and therefore more predictable.").

218. See Berger-Walliser, supra note 20, at 1295-96 (citing to Council Regulation, art. 7 as an example of a complex special jurisdiction rule).

219. See Council Regulation 1215/2012, supra note 202, at art. 36(1) ("Under no circumstances may a foreign judgment be reviewed as to its substance.").

220. See Council Regulation 1215/2012, supra note 202, at art. 4(1) ("If the defendant is not domiciled in a Member State, the jurisdiction of the courts of each Member State shall, subject to Articles 22 and 23, be determined by the law of that Member State.").

221. Council Regulation 1215/2015, supra note 202, at art. 4(1); see also Council Regulation 1215/2012, supra note 202, at pmbl. 13 ("In relation to insurance, consumer contracts and employment, the weaker party should be protected by rules of jurisdiction more favourable to his interests than the general rules provide for."). 
of the EU, however, are not covered by the regulation's sphere of application. The extension of the Brussels Regulation's jurisdictional rules to third countries was one of the most contentious issues during the recast, but ultimately was not retained. ${ }^{222}$ Thus, in cases between an EU plaintiff and a non-EU defendant, the national court continues to apply its domestic rules of jurisdiction. ${ }^{223}$ Because they represent a harmonized system, the following section concentrates on the Brussels Regulation's jurisdiction rules and analyzes how they apply to human rights abuse victim's claims against corporate defendants domiciled in the EU.

\section{B. Brussels Regulation and Human Rights}

The Brussels regulation, similar to settled personal jurisdiction rules in the United States, distinguishes between general and, what the regulation calls, special jurisdiction.

\section{General Jurisdiction}

According to Article 4(1) of the Brussels Regulation, which by virtue of Article 63(1) also applies to corporations, ${ }^{224}$ "persons domiciled in a Member State shall, whatever their nationality, be sued in the courts of that Member State."225 This broad jurisdictional norm is reminiscent of the Supreme Court's "at home" test. ${ }^{226}$ Neither the plaintiff needs to be

222. See BAumgartner, supra note 208, at 37-38 (noting that the proposal to extend Council Regulation, art. 6(2), though it ultimately was not retained, "garner[ed] considerable interest in the United States"); see also Commission Proposal for a Regulation of the European Parliament and of the Council on Jurisdiction and the Recognition and Enforcement of Judgments in Civil and Commercial Matters, COM (2010) 748 final (Dec. $14,2010)$ (deciding not to include the extension of the Brussels' Regulations to third parties).

223. See Council Regulation 1215/2012, supra note 202, at pmbl. 14 ("The autonomy of the parties to a contract, other than an insurance, consumer or employment contract, where only limited autonomy to determine the courts having jurisdiction is allowed, must be respected subject to the exclusive grounds of jurisdiction laid down in this Regulation."); see also Council Regulation 1215/2012, supra note 202, at art. 6 (outlining where a person domiciled in a Member State may sue).

224. See Council Regulation 1215/2012, supra note 202, at art. 63(1) (“A company or other legal person or association of natural or legal persons is domiciled at the place where it has its: (a) statutory seat; (b) central administration; or (c) principal place of business.”).

225. Council Regulation 1215/2012, supra note 202, at art. 4(1).

226. See Goodyear Dunlap Tires Operations S.A. v. Brown, 564 U.S. 915, 919 (“A court may assert general jurisdiction over foreign (sister-state or foreign-country) corporations to hear any and all claims against them when their affiliations with the State are so "continuous and systematic' as to render them essentially at home in the forum State" (citing Int'l Shoe Co. v. State of Wash., 326 U.S. 310, 317 (1945))). 
domiciled in the EU, nor does the case need to represent a close connection to the territory of an EU member state as long as the defendant is domiciled in the forum state. ${ }^{227}$ This has led some European commentators to assume that, according to Brussels Regulation Article 4(1), any EU-based MNC may be sued for its involvement with human rights abuses before the courts in its home country, even if the latter were committed in a third country. ${ }^{228}$ Others have taken a more careful stance, arguing that due to extraterritoriality and sovereignty concerns, home-state jurisdiction in the EU should be limited to cases where the tortious act or negligence can be situated in the home state. ${ }^{229}$ In fact, all European human rights cases against corporate defendants so far have been based on direct foreign liability, that is, violation of proper surveillance or other duties on the part of the parent company at their European headquarters, rather than vicarious liability for human rights violations committed by a corporation's employee or subsidiary abroad. ${ }^{230}$

General jurisdiction based on Article 4(1) will only lead to jurisdiction if the company is being sued before the courts in its home state. There have been attempts to use Article 63(1) to attribute general jurisdiction over an EU subsidiary to the non-EU parent and the other way around. Under the Brussels Regulation, a corporation's principal place of business is where the main business activities are located. ${ }^{231}$ According to a decision by the ECJ,

227. See Jan Wouters \& Cedric Ryngaert, Litigation for Overseas Corporate Human Rights Abuses in the European Union: The Challenge of Jurisdiction, 40 GEO. WASH. INT'L L. REV. 939, 945 (2009) ("This is also the interpretation of the European Parliament, which, in 2002, drew 'attention to the fact that the 1968 Brussels Convention [as consolidated in the Brussels Regulation] enables jurisdiction within the courts of Member States for cases against companies registered or domiciled in the E.U. in respect of damage sustained in third countries." (citing Commission Green Paper on Promoting a European Framework for Corporate Social Responsibility, at 50, COM (2001) 366 final (May 30, 2002))).

228. Ingrid Heinlein, Zivilrechtliche Verantwortung transnationaler Unternehmen für sichere und gesunde Arbeitsbedingungen in den Betrieben ihrer Lieferanten, NEUE ZEITSCHRIFT FÜR ARBEITSRECHT 276, 278 (2018) (Ger.); Marc-Philippe Weller, Luca Kaller \& Alix Schulz, Haftung deutscher Unternehmen für Menschenrechtsverletzungen im Ausland, 216 ArCHIV FÜr Civilistische PraXis 387, 391 (2016) (Ger.).

229. See Wouters \& Ryngaert, supra note 227, at 954-55 ("Courts should weigh, on the one hand, the duty of home states to see to it that their TNCs behave correctly in host states and, on the other hand, home states' duty not to interfere in the economic policies of host states.") (internal citations omitted).

230. See Wouters \& Ryngaert, supra note 227, at 951 ("This is arguably so because in the former situation the violation (of the duty of care) occurred in Europe, while in the latter case it occurred abroad.").

231. See Notice of Proposed Amendment No 09/2005, Draft Opinion of the European Aviation Safety Agency, at 5 (Dec. 6, 2005), https:/www.easa.europa.eu/sites/default/files/df u/NPA-09-2005.pdf [https://perma.cc/5WH9-BQFL] (noting that "it is a general understanding that the concept of principal place of business should be construed to mean a 
a branch, agency, or other dependent establishment do not qualify as a corporation's domicile under Article 63. ${ }^{232}$ Article 63(1) does not permit "piercing the jurisdictional veil" to establish general jurisdiction over the parent via its dependent branch in an EU member state. ${ }^{233}$

In contrast, U.S. human rights litigation against parent companies has often focused on the agency relationship between parent and subsidiary, both as a matter of substantive and procedural law. ${ }^{234}$ Compared to Brussels Regulation Article 63(1), which clearly enumerates under which circumstances a corporation can be sued in its home jurisdiction, the Supreme Court's "at home" test for general jurisdiction is less specific and, in this regard, offers more room for interpretation. ${ }^{235}$ Considering this, it seems possible for a court in the United States to establish general personal jurisdiction over a foreign parent based on the latter's in-state subsidiary, if, for example, decision-makers in both companies were identical or the parent in fact controlled the legally independent subsidiary. ${ }^{236}$

In the EU, it is an open question whether it is possible to interpret Article 63(1) to locate the domicile of the (non-European) subsidiary of an EU parent company in the EU, and thus to establish general jurisdiction over the non-EU subsidiary, based on Brussels Regulation Article 4(1). Plaintiffs in a case before U.K. courts claimed that the "central administration" of a South African subsidiary of an U.K. company was in the U.K. and thus in the European Union, because "the real decisions were taken in the U.K.,

permanent and regular place of transacting of general business and would not include a temporary place of sojourn during ad hoc negotiations. It should as well indicate where is the seat of the management of the interests of the organization or its guiding activity.").

232. Case 33/78, Somafur SA v. Saar-Ferngas, 1978 E.C.R. 2183-93.

233. That follows from art. 7 (5). Council Regulation 1215/2012, supra note 202, at art. 63(1); see also Lea Brilmayer \& Kathleen Paisley, Personal Jurisdiction and Substantive Legal Relations: Corporations, Conspiracies, and Agency, 74 CAL. L. Rev. 1, 14, 10, 25 (1986) (noting that merging a parent and subsidiary for jurisdictional purposes requires an inquiry "comparable to the corporate law question of piercing the corporate veil").

234. Wouters \& Ryngaert, supra note 227, at 951 n.46 (citing JENNIFER ZERK, MultinAtionals AND CoRPORATE Social ReSPONSIBILITY 223-25 (2006)).

235. See Gerlinde Berger-Walliser, Reconciling Transnational Jurisdiction: A Comparative Approach to Personal Jurisdiction over Foreign Corporate Defendants in US Courts, 51 Vand. J. TRansnat'L L. 1243, 1293 (2018) (“Though the Court rejected the Ninth Circuit's agency approach to establishing general jurisdiction in Daimler, it did not expressly exclude other ways of establishing derivative jurisdiction over the foreign parent through an independent subsidiary in the forum state.") (citing Daimler AG v. Bauman, 571 U.S. 117, $135(2014))$.

236. The issue was raised in Daimler, but ultimately not decided, because plaintiffs never "maintained that MBUSA was an alter ego of Daimler." Daimler AG v. Bauman, 571 U.S. 117,134 (2014). 
where the parent company ... had its seat." ${ }^{, 237}$ Article 6(1) of the European Convention on Human Rights (ECHR), ${ }^{238}$ which guarantees a right of access to a court, could support this broad interpretation. ${ }^{239}$ On the other hand, predictability and efficiency, two other objectives of the Brussels Regulation, may speak against it. ${ }^{240}$

Hence, under the Brussels Regulation, derivative jurisdiction is an issue of specific rather than general jurisdiction. Most cases in the relatively recent history of European human rights litigation against corporate defendants have been brought against the European parent companies in their home countries under Article 4(1). Accordingly, the following examination of the Brussels Regulation's special jurisdiction rules will analyze scholarship and ECJ decisions in other areas and speculate how they might apply to cases where plaintiffs attempt to sue non-EU companies before private courts in an EU member state.

\section{Derivative Special Jurisdiction based on a Subsidiary's Domicile}

Article 7(5) of the Brussels Regulation stipulates that "a dispute arising out of the operations of a branch, agency[,] or other establishment" can be brought "in the courts for the place where the branch, agency[,] or other

237. Marta Requejo Isidro, Business and Human Rights Abuses: Claiming Compensation under the Brussels I Recast, 10 Hum. RTs. \& InT'L LegAL Discourse 72 (2016) (referencing the ultimately unsuccessful UK case, Vava and others v. Anglo American South Africa Limited, [2013] EWHC (QB) 2131).

238. See generally Convention for the Protection of Human Rights and Fundamental Freedoms, Sept. 3, 1953, 213 U.N.T.S. 221 (providing fundamental freedom and human rights protections submitted by the Council of Europe).

239. See Berger-Walliser, supra note 20, at 1287 (stating that "the right to a fair trial 'requires that litigants should have an effective judicial remedy enabling them to assert their civil rights"” (quoting EuRopean COURT of Human Rights, Guide on ARTicle 6 of the European Convention on Human Rights 18 (Dec. 31, 2017))); see also Requejo Isidro, supra note 237, at 78 (referring to an ECJ decision, where the court had acknowledged the need to extend Art. 4(1) "to cases of unknown domicile of the defendant, provided that 'no firm evidence' of a domicile outside of the EU has been adduced" (citing Case C-327/10 (2011); Case C-2929/10 (2012)).

240. See Berger-Walliser, supra note 20, at 1296 (pointing to examples of special heads of jurisdiction in the Brussels Regulation, which above all aim at improving "efficiency of court proceedings"); see also Requejo Isidro, supra note 237, at 80 (noting that "it is worth stressing that the assessment of jurisdiction is an early procedural step that ought not lead to extended legal argument, cost and time) (citing Case C-327/10, para. 42). It should be noted that the drafters of the Brussels Regulation did not retain a proposal for forum necessitatis in the final version of the regulation, hence it is questionable if there is room for such an approach within the strict system of the regulation; contra Requejo Isidro, supra note 237, at 81 (arguing that the ECJ's case C-327/10, para. 45, might point in this direction). 
establishment is situated." ${ }^{241}$ If a sufficient nexus between the parent and the acting entity in question has been established as to qualify as a "branch, agency[,] or establishment" under Article 7(5), the plaintiff will be able to sue the foreign parent corporation in the forum where he or she was harmed by the subsidiary's operations. Article 7(5) would allow plaintiffs to sue, for example, a Spanish parent company with a dependent subsidiary in France if this was where the plaintiff was harmed. ${ }^{242}$ In this regard, Article 7(1) is of limited use in international human rights cases, where the abuse typically is committed by a foreign subsidiary outside of the EU. ${ }^{243}$

However, individual EU member states have similar provisions as part of their domestic civil procedure law, which, in cases against non-EU defendants replace the Brussels Regulation for a domestic court to determine its international competence to decide an international case. Section 21(1) of the German Code of Civil Procedure, for example, provides that a parent company can be sued at the place where its branch or subsidiary is located. ${ }^{244}$ For that to be possible, the subsidiary needs to have a certain degree of independence that lacks, for example, in the case of a simple contact office, warehouse, or exposition stand, but would be given in the case of a bank branch like Arab Bank's New York branch. ${ }^{245}$ It does not follow, however, that based on section 21(1) German courts would necessarily grant jurisdiction over Arab bank if a similar case had presented itself before a German court. For section 21(1) to establish jurisdiction over the foreign parent corporation, there also needs to be a connection between the claim and the activities of the branch. ${ }^{246}$ Though, arguably, in Jesner, there has been some activity related to the claim performed by the New York branch in the forum state-alleged CHIP transactions as well as money laundering activities for the Texas-based charity-plaintiffs, as the United States

241. Council Regulation 1215/2012, supra note 202, at art. 7(5).

242. See Berger-Walliser, supra note 20, at 63 ("While Article 7(5) only applies to corporate defendants domiciled in an EU member state, it was modeled after similar provisions in the domestic civil procedure law of its member states. As a result, a US company that is sued in an EU member state based on the activities of its European branch or subsidiary is likely to be exposed to similar jurisdiction rules.") (internal citations omitted).

243. Council Regulation 1215/2012, supra note 202, at art. 4(1) determines, at the same time, general personal jurisdiction and the regulation's sphere of application.

244. See Zivilprozessordnung [ZPO] [Code of Civil Procedure], Title 2, § 21, https: //www.gesetze-im-internet.de/zpo/ [https://perma.cc/8ATX-M5VL] (proving that a parent company may be sued at the location of its subsidiary or branch).

245. See Reinhard Patzina, in 1 MünChENER Kommentar zUR ZiviLPROZESSORDNung 243 (Wolfgang Krüger \& Thomas Rauscher eds., 2016) (Ger.) (referencing BGH WM 1987, $1089,1090)$.

246. See id. at 244 (noting that contracts concluded by the subsidiary in the forum state and torts committed by the subsidiary establish a sufficient connection). 
Supreme Court argued in Jesner, were harmed outside of the forum state. ${ }^{247}$ If this, in light of extraterritoriality concerns in international human rights cases, is enough to establish a sufficient connection under section 21(1), it is equally questionable as to establish general jurisdiction under Brussels Regulation Article 4(1) in cases where victims were harmed in a third country. ${ }^{248}$ Since the only human rights case presented before a German court so far was based on a negligence claim against the German parent company rather than an agency relationship with its subsidiary, the issue has not yet been decided in German jurisprudence. ${ }^{249}$

\section{Special Tort Jurisdiction}

Since most European substantive claims have been based on direct liability, special jurisdiction over either the subsidiary, the parent, or both, at the place where the tort has been committed seems like an obvious choice. In this regard, the United States Supreme Court has limited specific jurisdiction over a foreign parent company in cases where "the defendant's activities manifest an intention to submit to the power of a sovereign." ${ }^{250}$ In Walden it required the "defendant himself" to have created "the necessary contacts with the forum." ${ }^{251}$ Hence, the question is whether the Brussels Regulation takes a position more favorable to human rights victims/plaintiffs. The regulation provides in Article 7 that "[a] person domiciled in a Member State may be sued in another Member State: . . . (2) in matters relating to tort, delict or quasi-delict, in the courts for the place where the harmful event occurred or may occur.",252

Hence, the availability of a domestic court in an EU member state to judge human rights abuses committed in third countries largely depends on how "the place where the harmful event occurred" is determined. This

247. See Jesner v. Arab Bank, PLC, 138 S. Ct. 1386, 1390 (2018) (noting that "petitioners are foreign nationals seeking millions of dollars in damages . . . for injuries suffered in attacks by foreign terrorists in the Middle East").

248. See supra Part III(B)(1).

249. See Burkhard Hess \& Martina Mantovani, Current Developments in Forum Access: Comments on Jurisdiction and Forum Non Conveniens, n.148 (Max Planck Inst. Lux. for Procedural L., Research Paper Series No. 2019(1), 2019), https://papers.ssrn.com/sol3/paper s.cfm?abstract_id=3325711 [https://perma.cc/BP6G-4DVY] (discussing the Kik case that is pending before Landgericht of Dortmund in Germany).

250. J. McIntyre Mach., Ltd. v. Nicastro, 564 U.S. 873, 882 (2011).

251. Gerlinde Berger-Walliser, Reconciling Transnational Jurisdiction: A Comparative Approach to Personal Jurisdiction over Foreign Corporate Defendants in US Courts, 51 VAND. J. TRansnat'L L. 1243, 1293 (2018) (citing Walden v. Fiore, 571 U.S. 277, 284 (2014)) (internal citations omitted).

252. Council Regulation, 1215/2012, supra note 202, at art. 7(2). 
criterion, in European commentary and ECJ case law, has been interpreted broadly as both the place where the damage occurred and the place where the harmful event giving rise to the damage occurred. ${ }^{253}$ The damage typically occurs at the place where the event, which gives rise to the dispute, produces and inflicts its harmful effects on the victim-as, for example, the terror attacks in Israel that Arab Bank allegedly supported through its financial transactions. ${ }^{254}$ Since in the human rights cases in question, the damage usually occurs in a third country, only the second alternative-if any-could lead courts in an EU member state to acknowledge jurisdiction under Article 7(2).

Generally, the harmful event relates to the tortfeasor's conduct or activities. ${ }^{255}$ This means that in a human rights case brought against a foreign corporation before a domestic court in an EU member state, one would need to localize the harmful event giving rise to the damage in that country. This, at first sight, seems easy to accomplish. If the activities of the defendant in the EU, for example financial transactions, contributed to human rights abuses in the plaintiff's home state, jurisdiction in the EU based on the place where the harmful event occurred seems to be established. A closer analysis, however, raises the question of whether any causal relationship between the activities or, in the case of negligence, the omission, suffices to establish jurisdiction under Article 7(2). The majority in Jesner found Arab Bank's activities in New York inconsequential compared to the terrorist attacks in Israel. ${ }^{256}$ According to the prevailing opinion in European scholarship and some isolated court decisions on the matter, "any relevant activity matters if the tortious conduct consists of a majority of elements." 257 "[M]ere acts of preparation," however, "are not covered.", preparation" is less clear. The ECJ, in cases concerning trademark infringement on the Internet through keyword advertisement found that "[t]he event giving rise to a possible infringement of trade mark law . . . lies in the actions of the advertiser using the referencing service for its own

253. See Berger-Walliser, supra note 20, at 1297-98 ("If these places are located in different member states, the plaintiff has the privilege of choice.”) (citing Case 21/76, Handelskwekerij G. J. Bier BV v. Mines de potasse d'Alsace SA, 1976 E.C.R. 1747).

254. See Peter Mankowski, Article 7, in 1 European Commentaries on Private InTERNATIONAL LAW 47, 121, 202 (Ulrich Magnus \& Peter Mankowski, eds., 2016) (explaining that, "[i]n principle, the place of the damage connotes the place where the physical damage is done") (internal citations omitted).

255. Id. at 281 .

256. See Jesner v. Arab Bank, PLC, 138 S. Ct. 1386, 1391 (2018) (referring to the alleged activities performed on U.S. territory as a "relatively minor connection").

257. Mankowski, supra note 254, at 281 (internal citations omitted).

258. Id. at 283. 
commercial communications," not the technical service of the provider. ${ }^{259}$ One European commentator has suggested to ask whether "the law of the state where the activity in question can be located ... regards such activity already to be a tortious activity." ${ }^{260}$ This approach admittedly is complicated because it requires substantive considerations already at the jurisdictional stage ${ }^{261}$ However, it has the merit of creating synergies between jurisdiction and the ultimately applicable law to the case. Thus, it would prevent a court from hearing a case if there is no prospect for an underlying substantive claim. ${ }^{262}$ Given the substantial differences in how courts worldwide currently treat corporate liability for human rights, the alignment of procedural and substantive law might be a promising solution for private human rights litigation. Though it does not necessarily extend victims' access to courts, it avoids protection gaps and unnecessary lawsuits with no prospect of success through the synchronization of jurisdictional and substantive law.

If one were to apply this approach to the facts underlying the Jesner litigation and under the hypothesis that the case happened in an EU member state, the plaintiff would need to show that (1) Arab Bank performed activities in that EU member state; (2) these activates ultimately caused harm; and (3) these activities are considered tortious by the law applicable to the case. While the outcome largely depends on factual questions, it should be noted that Article 7(2) does not allow imputing third parties' (here Arab Bank branch's) activities to the parent corporation. The latter would be a case of Brussels Regulation Article 7(5). Hence, the parent's activities themselves need to qualify as tortious activity according to the aforementioned definition and need to have been performed in the forum state. Based on the facts in Jesner, it is questionable if the parent's involvement with the branch's financial transactions would suffice. One could argue that they were initiated by the parent and that it is the parent company who actually made the decisions. However, these decisions were likely made at Arab Bank's headquarters and thus not in the forum state. With regard to the dollar clearances using the CHIP system, which actually

259. ECJ Case C-523/10, para. 35 citing Google France and Google, paragraphs 52 and 58 .

260. Mankowski, supra note 254, at 283.

261. However, this approach is not unusual. See, e.g., Council Regulation 1215/2012, supra note 202, at art. 7(1)(b) (stating jurisdiction in matters relating to contracts for the sale of goods refers to "the place in a Member State where, under the contract, the goods were delivered or should have been delivered").

262. See Mankowski, supra note 254, at 283 (arguing that "it is for the law at the place of activity to decide whether and to which extend it is willing to protect which values and how low or how high it sets the threshold"). 
occurred in the forum state, one could argue that these mechanical transactions were not tortious in themselves and thus - similar to an Internet provider's uploading activities - mere preparatory acts. In conclusion, the facts in Jesner probably would have led a court in an EU member state to deny jurisdiction over Arab Bank based on Article 7(2), however, under a different fact scenario, Article 7(2) could create jurisdiction in an EU member state over an alien parent for its involvement in human rights abuses in a third country.

\section{Special Jurisdiction for Connected Claims}

Finally, the Brussels Regulation, in Article 8(1), as well as some member states' domestic counterparts, provide a special head of jurisdiction for connected claims. It has been used, for example, in a Dutch case to establish jurisdiction over a Nigerian subsidiary at the domicile of the parent company in the Netherlands based on the relationship of the claim against the latter. The Dutch court even continued to hear the case against the Nigerian subsidiary after it dismissed the claim against the Dutch parent. ${ }^{263}$ The underlying rationale of Article $8(1)$ is based on efficiency considerations. Connected claims may be brought before a single court if they are "so closely connected that it is expedient to hear and determine them together to avoid the risk of irreconcilable judgements resulting from separate proceedings." ${ }^{264}$ In the context of private human rights claims, it has been suggested that the meaning of "related claims" be determined more explicitly according to a proposal made by the International Law Association's Committee on Civil Litigation \& the Interests of the Public. ${ }^{265}$ The Committee's final report suggests a definition of connected claims "based on the efficiency of hearing them together and on the defendants being related." 266 According to the committee's proposal, to be related (a) the defendants need to be part of the same corporate group; (b) one defendant needs to have controlled the other defendant; (c) one defendant directed the litigious acts of the other defendant; or they took part in a concerted manner

263. See Requejo Isidro, supra note 237 , at $81-82$ (hearing the claim against the subsidiary after the claim was dismissed against the parent).

264. See Horatia Muir Watt, Article 8, in 1 European Commentaries on Private International LAW 373 (Ulrich Magnus \& Peter Mankowski, eds., 2016) (citing Case 189/87, 1988 ECR 5565) (holding that clearly connected claims can be brought before a single court).

265. See Requejo Isidro, supra note 237, at 82-83 (referencing the International Law Association, Committee on Civil Litigation \& the Interests of the Public, Final Report on the Subject of International Civil Litigation for Human Rights Violations, Sofia, 2012).

266. Requejo Isidro, supra note 237 , at 83. 
in the activity giving rise to the suit. ${ }^{267}$ Whether specific jurisdiction based on related claims constitutes a viable option for proceedings before U.S. courts is questionable due to constitutional due process concerns, which typically lead courts to favor defendant protection over efficiency considerations. ${ }^{268}$

\section{CONCLUSION}

With the door closing on ATS litigation for corporate human rights abuses in the United States, foreign plaintiffs will have to look not only for new ways to substantiate their claims, but also for alternative jurisdictional grounds to enforce their rights. These are likely to be limited by constitutional due process considerations. Following the Court's decision in Daimler, courts will continue to have general personal jurisdiction over corporations in their home state, but extraterritoriality concerns could even limit general jurisdiction in cases where the harmful event took place outside the United States.

Against the background of recent Supreme Court decisions, suing a foreign-headquartered MNC in the United States will most likely prove even more difficult. However, the above analysis has shown that space remains for a more plaintiff-friendly interpretation of the Court's special jurisdiction rules. For guidance, this Article has looked at European jurisdictional rules and court practice outside the ATS, which, after all, has always been a U.S. exception criticized by foreign governments. Though domestic courts in EU member states have a shorter tradition of corporate human rights litigation than federal courts in the United States, against the background of the advancement of the business and human rights agenda, recent trends for a more active role of European courts to enforce human rights against corporations have emerged. Most European private human rights litigation has been brought against European companies in their home states based on direct foreign liability claims. This trend is likely to increase based on the due diligence regulation enacted in some European countries. Unlike existing or proposed U.S. corporate reporting provisions on corporate human rights impact, these laws place substantive monitoring duties on European

267. See Requejo Isidro, supra note 237, at 83 (citing Guideline 2.2(2) and (3)).

268. See Gerlinde Berger-Walliser, Reconciling Transnational Jurisdiction: A Comparative Approach to Personal Jurisdiction over Foreign Corporate Defendants in US Courts, 51 Vand. J. TRansnat'L L. 1243, 1303 (2018) (concluding that "[w] here the U.S. Supreme Court protects defendants' due process rights and the sovereignty of US states, the Brussels Regulation strives for harmonization of jurisdictional rules between member states and access to justice for the plaintiff."). 
companies and could inspire reforms in U.S. federal or state law. Moreover, European jurisdictional rules offer possibilities for foreign plaintiffs to sue even non-EU MNCs before European domestic courts. These rules could potentially be transposed to the United States context, despite fundamental differences in U.S. and EU jurisdiction law and the narrow circumstances in which these rules apply. Especially in connection with the rise of the substantial due diligence obligation mentioned, a jurisdictional rule that relies on the place where the harmful event giving rise to the damage occurred does not only protect plaintiffs' access to justice rights, but also could bring jurisdictional rules in line with the "lex loci delicti" rule traditionally used to determine the applicable law of an international tort case. Doing so would prevent courts from having to apply a different law than their own to the case, which, in turn, would promote legal certainty and efficiency. It also would make personal jurisdiction consistent with federal venue rules. ${ }^{269}$ In international human rights litigation, the lack of effective protection in a plaintiff's home country may justify this type of specific personal jurisdiction over foreign corporations in cases where corporate actions, which gave rise to the suit, took place in the forum state, and no effective alternative forum exists in the plaintiff's home country.

While the academic discussion on private human rights litigation has primarily focused on substantive claims, this Article has underscored the importance of jurisdictional rules as part of an effective enforcement mechanism for human rights. In light of the recent changes on both sides of the Atlantic, now might be a good time for courts and regulators to develop a coherent legal regime to hold corporations accountable for their involvement in international human rights abuses, which embraces both substantive and procedural rules. More balanced and predictable rules would not only improve plaintiffs' rights, but also provide guidance to MNCs who continue to be reluctant to adopt human rights as part of their Corporate Social Responsibility. Finally, the UN Guiding Principles call on states to provide access to a remedy as part of their third pillar. Thus, they suggest facilitating court access for human rights victims rather than restricting it.

269. See J. McIntyre Mach., Ltd. v. Nicastro, 564 U.S. 873, 899 (2011) (pointing towards 28 U.S.C. $\S 1391$ (a)-(b) and noting "in federal-court suits, whether resting on diversity or federal-question jurisdiction, venue is proper in the judicial district 'in which a substantial part of the events or omissions giving rise to the claim occurred"'). 